\title{
1 SARS-CoV-2 transmission and control in a hospital setting: an individual-based
}

\section{2 modelling study}

3 Running title: SARS-CoV-2 transmission and control in a hospital setting

4 Qimin Huang, $\mathrm{PhD}^{1 \#}$; Anirban Mondal, $\mathrm{PhD}^{1 \#}$; Xiaobing Jiang, $\mathrm{PhD}^{2 \#}$; Mary Ann Horn, $\mathrm{PhD}^{1}$; Fei

5 Fan, $\mathrm{MD}^{2}$; Peng Fu, $\mathrm{MD}^{2}$; Xuan Wang, $\mathrm{MD}^{2}$; Hongyang Zhao, $\mathrm{PhD}^{2 *}$; Martial Ndeffo-Mbah,

$6 \quad \mathrm{PhD}^{3,4 *}$; David Gurarie, $\mathrm{PhD}^{1,5}$.

$7 \quad{ }^{1}$ Department of Mathematics, Applied Mathematics and Statistics, Case Western Reserve University,

8 Cleveland, OH, USA, 44106.

$9 \quad{ }^{2}$ Department of Neurosurgery, Union Hospital, Tongji Medical College, Huazhong University of

10 Science and Technology, Wuhan, China, 430022.

$11{ }^{3}$ Department of Veterinary and Integrative Biosciences, College of Veterinary and Biomedical

12 Sciences, Texas A\&M University, College Station, TX, USA, 77840;

$13{ }^{4}$ School of Public Health, Texas A\&M University, College Station, TX, USA, 77840.

$14{ }^{5}$ Center for Global Health and Diseases, School of Medicine, Case Western Reserve University, Cleveland,

15 OH 44106, USA;

16 \# These authors contributed equally to this study.

$17 *$ Correspondence:

18 Martial Ndeffo-Mbah, PhD, Department of Veterinary and Integrative Biosciences, College of

19 Veterinary and Biomedical Sciences, Texas A\&M University, College Station, TX, USA, 77840;

20 Tel: 1-979-845-5646; E-mail: mndeffo@cvm.tamu.edu. 
medRxiv preprint doi: https://doi.org/10.1101/2020.08.22.20179929; this version posted August 25, 2020. The copyright holder for this preprint (which was not certified by peer review) is the author/funder, who has granted medRxiv a license to display the preprint in perpetuity.

It is made available under a CC-BY-NC-ND 4.0 International license .

21 Hongyang Zhao, MD, PhD, Department of Neurosurgery, Union Hospital, Tongji Medical College,

22 Huazhong University of Science and Technology, Wuhan 430022, China. Tel: 86-27-85350791; E-

23 mail: hyzhao750@sina.com

\section{Abstract}

25 Background Development of strategies for mitigating the severity of COVID-19 is now a top global

26 public health priority. We sought to assess strategies for mitigating the COVID-19 outbreak in a

27 hospital setting via the use of non-pharmaceutical interventions such as social distancing, self-

28 isolation, tracing and quarantine, wearing facial masks/ personal protective equipment.

29 Methods We developed an individual-based model for COVID-19 transmission among healthcare

30 workers in a hospital setting. We calibrated the model using data of a COVID-19 outbreak in a

31 hospital unit in Wuhan in a Bayesian framework. The calibrated model was used to simulate

32 different intervention scenarios and estimate the impact of different interventions on outbreak size

33 and workday loss.

34 Results We estimated that work-related stress increases susceptibility to COVID-19 infection among

35 healthcare workers by 52\% (90\% Credible Interval (CrI): 16.4\% - 93.0\%). The use of high efficacy

36 facial masks was shown to be able to reduce infection cases and workday loss by $80 \%$ (90\% CrI:

$3773.1 \%-85.7 \%$ ) and $87 \%$ (CrI: $80.0 \%-92.5 \%$ ), respectively. The use of social distancing alone,

38 through reduced contacts between healthcare workers, had a marginal impact on the outbreak. A

39 strict quarantine policy with the isolation of symptomatic cases and a high fraction of pre-

40 symptomatic/ asymptomatic cases (via contact tracing or high test rate), could only prolong outbreak

41 duration with minimal impact on the outbreak size. Our results indicated that a quarantine policy 
medRxiv preprint doi: https://doi.org/10.1101/2020.08.22.20179929; this version posted August 25, 2020. The copyright holder for this preprint (which was not certified by peer review) is the author/funder, who has granted medRxiv a license to display the preprint in perpetuity. It is made available under a CC-BY-NC-ND 4.0 International license.

42 should be coupled with other interventions to achieve its effect. The effectiveness of all these

43 interventions was shown to increase with their early implementation.

44 Conclusions Our analysis shows that a COVID-19 outbreak in a hospital's non-COVID-19 unit can

45 be controlled or mitigated by the use of existing non-pharmaceutical measures.

46 Keywords: COVID-19, non-pharmaceutical interventions, hospital setting, individual-based model 
medRxiv preprint doi: https://doi.org/10.1101/2020.08.22.20179929; this version posted August 25, 2020. The copyright holder for this preprint (which was not certified by peer review) is the author/funder, who has granted medRxiv a license to display the preprint in perpetuity.

It is made available under a CC-BY-NC-ND 4.0 International license .

\section{Background}

48 The world is in the midst of an unprecedented coronavirus outbreak caused by a novel virus recently named COVID-19 by the World Health Organization (WHO). The outbreak which started in the city

50 of Wuhan, Hubei Province, China, in early December 2019 spread to many countries around the

51 world before being declared a pandemic by the WHO on March 11th, 2020.

52 Developing strategies for mitigating the severity of COVID-19 is now a top global health priority.

53 The range of containment strategies employed in different countries and regions varies from shelter-

54 in-place orders, the shutdown of public events, travel ban [1], and visitor quarantine, to intermediate

55 steps that involve partial closures (e.g. schools [2], workplaces, sporting, and cultural events) [3].

56 While such drastic steps can reduce infection spread, they exact a heavy toll on society and human

57 well-being. At present the only available means of containing COVID-19 spread is via the use of

58 non-pharmaceutical interventions [4, 5] such as social distancing, self-isolation [6], tracing and

59 quarantine $[6,7]$, wearing facial masks/ personal protective equipment (PPE) $[8,9]$.

60 Mathematical models of disease transmission are powerful tools for exploring this complex

61 landscape of intervention strategies and quantifying the potential benefits of different options [10-

62 13]. Traditional approaches in epidemiological modeling use compartmental models [14-16], which

63 assume a uniform population and simple mixing patterns with steady contact rates. Such models can

64 give qualitative answers for large-scale populations at best [17, 18], however, are not suitable to

65 account for the complexity and specifics of COVID-19 in local communities and small populations

66 (e.g., hospital, workplace, school). Such settings are characterized by heterogeneous populations,

67 multiple disease pathways, and complex social interactions. 
medRxiv preprint doi: https://doi.org/10.1101/2020.08.22.20179929; this version posted August 25, 2020. The copyright holder for this preprint (which was not certified by peer review) is the author/funder, who has granted medRxiv a license to display the preprint in perpetuity.

It is made available under a CC-BY-NC-ND 4.0 International license .

Our focus here is COVID-19 transmission in a hospital setting, where healthcare workers (HCWs) are at high risk to acquire infection through interactions with fellow HCW and with patients [19-22]. We developed a novel individual-based model (IBM) for COVID-19 transmission among HCWs, and applied it to explore the efficacy of different control/ mitigation strategies via non-

72 pharmaceutical interventions. IBMs have been used extensively to model pathogens spread on

73 different scales, from global pandemics [23-25], to local social networks [26]. On the disease side,

74 our IBM features distinct infective stages and transitions, observed in Covid-19, with some hosts

75 recovering without any symptoms, while others undergoing mild or severe infection pathways. On

76 the social side, we take into account individual behavior, including mixing patterns among HCW,

77 their use of facemasks and PPE, and HCW-patient interactions. All of these factors play an

78 important role in COVID-19 transmission.

79 The IBM model was calibrated in a Bayesian framework using empirical data from a non-COVID

80 hospital unit. We used our calibrated model to simulate different intervention scenarios, including

81 adaptive behavior (social distancing in the workplace, individual protection, isolation of infected

82 individuals). In each case, we assessed the effect of interventions on outbreak outcomes: outbreak

83 size, outbreak duration, and workday loss.

\section{Methods}

\section{Individual-based modelling methodology}

86 In our model, an individual can undergo a sequence of infection stages, classified as susceptible $(S)$,

87 pre-symptomatic/ asymptomatic $(E)$, two symptomatic stages $I_{1}$ (upper respiratory stage) followed

88 by $I_{2}$ (advanced infection stage, lungs et al.), and recovered/immune state $(R)$ (see Figure 1 ). These

89 states differ by their infectivity levels and stage duration. Unlike most other viral diseases, pre- 
medRxiv preprint doi: https://doi.org/10.1101/2020.08.22.20179929; this version posted August 25, 2020. The copyright holder for this preprint (which was not certified by peer review) is the author/funder, who has granted medRxiv a license to display the preprint in perpetuity.

It is made available under a CC-BY-NC-ND 4.0 International license .

symptomatic/asymptomatic COVID-19 hosts (E-stage) are known to transmit pathogens [27-29]. So we assign positive infectivity levels $\left(b_{0}, b_{1}, b_{2}\right)$ to all three stages $\left(E, I_{1}, I_{2}\right)$.

92 We modelled social mixing patterns by assuming that HCWs and ward patients interact on a daily

93 basis via aggregating in random groups of HCWs, and via patient visitation by HCWs (See SI in

94 details). The net outcome is a contact pool for each HCW-host, which varies randomly on a daily

95 basis. Each contact of a susceptible individual with infectious individuals (HCWs or patients) can

96 lead to infection (transition $S \rightarrow E$ ), with a probability that depends on infectivity levels of the

97 contact pool and the host susceptibility, $a$ ( $a=0$ - fully protected, $a=1$ - fully susceptible). The

98 latter depends on host health /immune status, individual behavior e.g. use of facial masks, and

99 environmental conditions. For instance, HCWs are supposed to use additional protection when

100 contacting patients. Then a probability of 'surviving' a single infective contact ( $\left.b_{i}\right)$ for an $S$-host of

101 susceptibility $a$, is given by $1-a b_{i}$. Combining all infective contacts of a given $S$-host, we get the

102 probability of infection $(S \rightarrow E), p_{s}=1-\prod_{i}\left(1-a b_{i}\right)$.

103 We divided all HCWs staff into susceptibility strata based on the hospital data [30]: (i) normal pool, $10460 \%$ of HCWs, have baseline susceptibility value, $a_{N}=0.5$; (ii) high-risk (stressed) pool, $40 \%$ of

105 HCWs, with susceptibility level, $0.5<a_{S}<1$ (to be calibrated).

106 Two points of our setup require some clarification: (i) the proposed form of social mixing in random

107 clusters extends the conventional 'social network' transmission pathways (see Figures. S1-S2); (ii)

108 an infective 'social contact' in our context means an event of sufficient duration and proximity, to

109 allow transmission of pathogens from infected to susceptible host [31]. 
110 There is much uncertainty on disease progression of infective stages. Here we assume infected $E$ -

111 hosts can undergo three different pathways: (A) asymptomatic $(E \rightarrow R)$; (M) mild symptomatic

$112\left(E \rightarrow I_{1} \rightarrow R\right) ;(\mathrm{S})$ severe symptomatic $\left(E \rightarrow I_{1} \rightarrow I_{2} \rightarrow R\right)$, with population fractions $\left(v_{A} ; v_{M} ; v_{S}\right)$.

113 In all cases, pre-symptomatic/ asymptomatic pool $(E)$ can carry and transmit the virus, along with

$114\left(I_{1}, I_{2}\right)$. Each infective stage $\left(E, I_{1}, I_{2}\right)$ has associated (mean) duration, $L_{E} ; L_{1} ; L_{2}$. The probability of

115 state transition $\left(E \rightarrow I_{1} ; I_{1} \rightarrow I_{2}\right.$, etc.) depends on the time, $d$, spent in a given disease state, relative

116 to the mean stage duration, $L$. Specifically, we use a Bernoulli distribution $B(p)$ of parameter, $p=$

$117 \Phi(d / L)$, with sigmoid $(0<\Phi(x)<1)$ of half-value, $x=1 / 2$.

118 During an outbreak, the HCWs expressing symptoms are tested, and certain fractions $\left(f_{1} ; f_{2}\right)$ of

$119\left(I_{1} ; I_{2}\right)$ are put in isolation, where they undergo their specific disease pathways, but do not mix and

120 transmit the pathogen. Two different types of diagnostic tests were used in the hospital, PCR for

121 light symptoms, and lung-scan for more severe conditions [30, 32]. Thus our assumed quarantine

122 fractions $\left(0<f_{i}<1\right)$ account for limited test sensitivity, and a possible overlap of 'COVID-like'

123 symptoms, expressed by non-COVID hosts. The recovered HCWs return to the work pool (see

124 Figure 1).

125 The model simulations were run on a daily basis and implemented in the Wolfram Mathematica

126 platform. The key inputs in the model include: 1) population makeup in terms of asymptomatic,

127 mild, and severe (A-M-S) progress groups, 2) initial infection status of HCW pool; 3) infectivity

128 levels $\left(b_{0}, b_{1}, b_{2}\right)$ for $\left(E, I_{1}, I_{2}\right)$ stages and susceptibility levels of individual hosts or host-pools; 4$)$

129 average duration of infective stages for (A-M-S) pathway; 5) daily social mixing patterns between

130 HCWs and infected patients; 6) daily isolation of symptomatic cases and recovery (See SI in details). 
medRxiv preprint doi: https://doi.org/10.1101/2020.08.22.20179929; this version posted August 25, 2020. The copyright holder for this preprint (which was not certified by peer review) is the author/funder, who has granted medRxiv a license to display the preprint in perpetuity.

It is made available under a CC-BY-NC-ND 4.0 International license .

\section{Model calibration}

132

Our model is calibrated to empirical data of a COVID-19 outbreak among HCWs in the department of neurosurgery of Union Hospital, Wuhan, China from January 5th, 2019 to February 4th, 2020 [30]. A Bayesian method is used to calibrate the following important parameters in our IBM: (i) mean infectivity $\left(b_{1}, b_{2}\right)$ of symptomatic hosts $\left(I_{1}, I_{2}\right)$, (ii) increased susceptibility level $\left(0.5<a_{S}<1\right)$ of the high-risk pool; (iii) fraction $v_{A}$ of HCWs going through the asymptomatic pathway $(E \rightarrow R)$. model parameters using the observed data on the daily incidence of symptomatic cases and the daily isolated cases. The prior distributions for all these parameters are taken to be uniform within acceptable ranges. The likelihood for the observed data is assumed as a normal distribution with the center at the predicted values from the IBM. The adaptive Metropolis algorithm [33] is used to

142 sample from the posterior distribution, where the jump size is adaptively chosen based on the sample

143 covariances. The chains are run for 10000 iterations, and after 5000 burin-in every 50th sample is

144 used as the final sample from the posterior distribution. To assess the convergence of the posterior

145 sampling, the Gelman-Rubin statistic [34] is computed for all the parameters. The statistics are found

146 to be very close to 1 , the desired value in strong support of convergence. The calibration was

147 implemented using R statistical software.

\section{Wuhan Hospital outbreak}

149 On December 26th, 2019, a patient later diagnosed with COVID-19 was admitted in the department

150 of neurosurgery of Union Hospital, Wuhan, China. No PPE was used by HCWs at that time. By

151 January 8th, HCWs started to show COVID-like symptoms (headache, cough, sore throat), and

152 screening and isolation were initiated among HCWs. From January 19th, patient's admission was 
medRxiv preprint doi: https://doi.org/10.1101/2020.08.22.20179929; this version posted August 25, 2020. The copyright holder for this preprint (which was not certified by peer review) is the author/funder, who has granted medRxiv a license to display the preprint in perpetuity.

It is made available under a CC-BY-NC-ND 4.0 International license .

153 stopped in the department, and the hospitalized patient pool was gradually reduced from 200 to 20

154 by the beginning of February. Over the period from January 5th to February 4th, 92 out of the 171

155 HCWs of the department were suspected or confirmed COVID-19 cases and isolated. New patients

156 were only admitted in early March 2020 when the pandemic was declared under control in Wuhan.

\section{Intervention strategies}

158 We consider three types of interventions: (i) social distancing (reduced contact rates) among HCWs 159 and individual protection (facial masks), (ii) enhanced screening and isolation of infected HCWs,

160 (iii) patient-pool control (pool size and infection level), and individual HCW protection via PPE.

161 For our baseline case, we assumed 50\% and 100\% isolation (quarantine) fractions of symptomatic

162 cases $\left(I_{1} ; I_{2}\right)$, respectively, and fixed infection level of the patient pool (see Table S1). To account

163 for model uncertainties, we run each control simulations for 100 posterior parameter samples and 5

164 stochastic model realizations for each sample (500 histories altogether), over a six-month period.

165 For social distancing, we considered 50\% and 75\% contact-rate reduction relative to their baseline

166 values. The effect of face mask on inter-staff or staff-patient mixing, was simulated by reduced

167 susceptibility of individual HCWs, with several values of mask efficacy [9]. Screening and isolation

168 fractions $\left(f_{i}\right)$ of HCWs were based on limited test sensitivity, combined with non-COVID

169 symptoms. An increase in targeted isolation assumes more intensive screening or test sensitivity. We

170 also studied the effect of isolating pre-symptomatic/ asymptomatic cases ( $E$-pool). This task is more

171 challenging, as PCR tests have lower sensitivity for such hosts [32], so to identify a suitable $E$ -

172 fraction would require intensive mass screening or contact tracing.

173 For quantitative assessment of control interventions and their impact, we use two measures: (1)

174 outbreak size = infection turnover (by the end of outbreak); (2) workday loss estimated from the 
medRxiv preprint doi: https://doi.org/10.1101/2020.08.22.20179929; this version posted August 25, 2020. The copyright holder for this preprint (which was not certified by peer review) is the author/funder, who has granted medRxiv a license to display the preprint in perpetuity.

It is made available under a CC-BY-NC-ND 4.0 International license .

175 quarantine pool over the outbreak duration. The latter gives a simple economic measure of outbreak

176 impact and putative interventions. In each control experiment, we compare the ratio of two outputs

177 (outbreak size and workday loss) to their baseline values, and record these relative values and their

178 distribution.

179 Another important factor in the hospital setting is the in-patient pool. In our case (a non-COVID unit

180 in Wuhan), it varied from the full capacity to zero. The key inputs of the patient pool included (i)

181 infected prevalence, (ii) mean patient infectivity to HCWs. The former is controlled by patient

182 admission and screening/isolation procedures; the latter can be modulated by using PPE. We also

183 explored the effect of different timing of PPE implementation and its efficacy.

\section{Results}

\section{Model calibration}

186 The predictions from the calibrated IBM were very close to the observed data on daily symptomatic

187 and quarantine cases (see Figure 2). The fraction of asymptomatic disease-progress pool, $v_{A}$, was

188 estimated at 0.308 (90\% Credible Interval (CrI): $0.163-0.395)$. So a sizable part of transmission

189 was carried over by undetected cases ( $E$-pool). Susceptibility level of the high-risk pool was

190 estimated at $a_{S}=0.76$ (90\% CrI: $\left.0.582-0.965\right)$. We attributed a higher susceptibility level to work-

191 stress, and our results gave a quantitative measure to this increase at 52\% (90\% CrI: $16.4 \%-93.0 \%)$

192 above the normal level. The infectivity levels of pre-symptomatic and symptomatic infections were

193 estimated to be 0.124 (90\% CrI: $0.111-0.144)$ and 0.225 (90\% CrI: $0.202-0.262)$. See SI Figure.

194 S3 for the prior and posterior probability distributions. 
medRxiv preprint doi: https://doi.org/10.1101/2020.08.22.20179929; this version posted August 25, 2020. The copyright holder for this preprint (which was not certified by peer review) is the author/funder, who has granted medRxiv a license to display the preprint in perpetuity.

It is made available under a CC-BY-NC-ND 4.0 International license .

196 The baseline scenario showed that almost all HCWs get infected, resulting in significant workday

197 loss, 1050 (90\% CrI: 913-1282) over the six-month period (Table 1 and SI Figure. S4). The impact

198 of implementing social distancing through reduction of contact rates alone and wearing facemasks

199 alone, from the start of the outbreak, was evaluated (Table 1). The reduction of contact rates alone

200 has a marginal effect on mitigating the outbreak in the long run. The $50 \%$ - drop of contact rates

201 leads to about 4\%-6\% reduction of the outbreak size and workday loss, while $75 \%$ - drop leads to a

$20215 \%-17 \%$ reduction, relative to baseline values. The efficacy of facemasks is uncertain, and we

203 explored several values $(50 \%, 67 \%, 75 \%, 85 \%, 95 \%)$, based on the previous studies [9]. We have

204 shown that wearing facemasks had a higher impact on mitigating the outbreak, than social distancing

205 (reduced contact rates). At 95\% efficacy, we could achieve 80\% (90\% CrI: 73.1\% - 85.7\%)

206 reduction of outbreak size, and $87 \%$ (CrI: 80.0\% - 92.5\%) of workday loss, compared to the

207 baseline.

208 Figure 3 illustrates the combined effect of facemask and social contact. We used the same values of

209 facemask efficacy and contact rates as Table 1. For each value of facemask efficacy, we observed a

210 consistent reduction of the outbreak size with reduced contact rates. It varied from 13\% - 34\% drop

211 for low-efficacy facemask (50\% protection), to 30\% - 60\% drop for high-efficacy facemask (95\%

212 protection). We observed a similar percentage reduction for the workday loss. So the impact of

213 reduction of contact rates was much greater under the higher efficacy of facemasks.

214 We also explored the effect of timing of intervention by the following three scenarios: (1) at the

215 beginning (Figure. 3A); (2) after the first identified case (Figure. 3B); (3) after 10\% of HCWs have

216 been identified as infected (Figure. 3C). Early interventions have made marked improvement under

217 different types of facemasks and contact rates. For instance, if control interventions (adoption of 
medRxiv preprint doi: https://doi.org/10.1101/2020.08.22.20179929; this version posted August 25, 2020. The copyright holder for this preprint (which was not certified by peer review) is the author/funder, who has granted medRxiv a license to display the preprint in perpetuity.

It is made available under a CC-BY-NC-ND 4.0 International license .

218 high-efficacy facemasks and reduced contact rates) were implemented at the start of the outbreak,

219 we observed $80 \%-90 \%$ reduction of the outbreak size (a near-complete control). A later

220 implementation (e.g. after the first identified case), gave $60 \%-85 \%$ reduction. If the timing was

221 delayed to e.g. 10\% identified cases, these numbers dropped to $40 \%-60 \%$. All intermediate cases

222 were shown in Figure. 3.

223 We next looked at the effect of HCWs screening and isolation via two scenarios. The first scenario

224 considered symptomatic cases only, by changing quarantine fraction $\left(f_{1}\right)$ of $I_{1}$, from its baseline

225 value $(50 \%)$ to $60 \%-100 \%$; quarantine fraction $\left(f_{2}\right)$ of $I_{2}$ was fixed at $100 \%$. Figure. 4 A shows

226 increased symptomatic isolation had only a marginal effect on the outbreak size, while raising

227 workday loss. A clue to low efficacy of symptomatic screening lies in (i) the role of pre-

228 symptomatic/ asymptomatic (E) pool in transmission, (ii) contribution of the patient source. To test

229 (i) we extended our quarantine strategy to pre-symptomatic/ asymptomatic cases $(E)$. Of course,

230 such an extension requires intensive screening of the work pool. Under random selection, isolating $f$

231 -fraction of $E$, would require much more than $f$-fraction of HCWs tested. For numeric simulations,

232 we fixed $\left(f_{1}, f_{2}\right)$ at $(90 \%, 100 \%)$, and varied $E$-fraction from $10 \%$ to $60 \%$. We still found the

233 effect of such a strategy was limited, it often prolongs the outbreak duration without affecting its

234 size. Besides, such a strategy can incur an economic burden by increased workday loss, though the

235 effect is subtler, as increased quarantine rate can slower transmission rate, hence fewer hosts would

236 be infected and need isolation. More significant progress was achieved by controlling the patient

237 source, via reduced patient prevalence (screening), or reduced infectivity (PPE) (see Figure. 4A-B).

238 We run several experiments with patient-pool control and PPE use (Figure. 4C). For PPE timing, we

239 made three choices: (i) the start of an outbreak, (ii) after the first identified HCW-case, (iii) no PPE 
medRxiv preprint doi: https://doi.org/10.1101/2020.08.22.20179929; this version posted August 25, 2020. The copyright holder for this preprint (which was not certified by peer review) is the author/funder, who has granted medRxiv a license to display the preprint in perpetuity.

It is made available under a CC-BY-NC-ND 4.0 International license .

use. We assumed PPE provides $80 \%$ protection (via the reduced probability of transmission from an infected patient). We also varied the infected prevalence level of the patient pool, from $0 \%$ to $5 \%$

242 (baseline case was 2\%). We found the control of patient infection (via e.g. PPE, screening and

243 isolation, particularly for new patients) can reduce outbreak size, even though the bulk of

244 transmission is carried over by inter-staff HCW contacts. We found the combined strategy (enhanced

245 HCW screening/isolation with patient control) could lead to marked improvement both in outbreak

246 size and in workday loss. This effect, however, is not observed for quarantine alone, under persistent

247 patient source.

248 Overall, we saw high-efficacy facemasks could provide the most effective control tool for reducing

249 COVID-19 transmission in HCW staff (Figure. 3).

\section{Discussion}

251 With the spread of COVID-19 in the world, the development of strategies for mitigating its severity

252 is a top public health priority. Large-scale population-level models of SARS-CoV-2 transmission

253 can give some qualitative answers for outbreak control on regional/country scales [35], however,

254 few studies have looked at the effects of interventions in a local community setting, such as hospital,

255 workplace, and school.

256 Using a novel individual-based modelling approach, we explored different scenarios for COVID-19

257 transmission and control in a non-COVID hospital unit. Our IBM methodology employed

258 conventional SEIR disease-stages with graded infectivity, extended to heterogeneous host makeup,

259 which includes multiple disease pathways, varying individual susceptibility, and behavioral patterns.

260 These factors can be affected by work stress, health status, use of face masks /PPE, and social

261 interactions. Social mixing was implemented in our model via inter-HCW contact pools and HCW- 
medRxiv preprint doi: https://doi.org/10.1101/2020.08.22.20179929; this version posted August 25, 2020. The copyright holder for this preprint (which was not certified by peer review) is the author/funder, who has granted medRxiv a license to display the preprint in perpetuity.

It is made available under a CC-BY-NC-ND 4.0 International license .

patient interactions. Control interventions included test diagnostics and isolation of established cases. Detailed data on the COVID-19 outbreak in the department of neurosurgery of Union Hospital in Wuhan (China) [30] was used to calibrate the essential model parameters. It included the onset of symptoms, diagnosis and isolation, and patient pool control, over the period January 5 th, through February 4th, 2020.

We allowed different disease-progress pathways: severe, mild, and asymptomatic (S-M-A), so the HCW-pool was partitioned into (S-M-A) progress groups. One of the key uncertain parameters was the asymptomatic-fraction, estimated at $31 \%$, a relatively high proportion of undetectable infections.

270 Another uncertain input was individual susceptibility, which could be affected by health status or

271 work stress. Based on data analysis [30], we divided the work pool into a normal group (60\% of

272 HCWs), and a high-risk group (40\% of HCWs). We estimated the high-risk susceptibility level

273 relative to normal susceptibility and found work-related stress could increase the risk of COVID-19

274 infection by up to $52 \%$.

275 The calibrated model was used to simulate a range of intervention scenarios, aimed at mitigating the 276 outbreak and examining its impact on the work pool. The baseline case, without interventions, gave 277 a large outbreak size, whereby almost all HCWs were infected over two months. It also incurred a 278 significant workday loss for the unit. Our results support early modeling findings of large-scale 279 populations, and subsequent empirical observations, that in the absence of control measures, a 280 COVID-19 epidemic could quickly overwhelm a region [12]. High-efficacy facemasks were shown 281 to be most effective for reducing infection cases and workday loss. The impact of social distancing 282 through the reduction of contact rates alone had an only marginal effect on mitigating the outbreak in 283 the long run. Reducing social contact rates to $50 \%$ (or $70 \%$ ) resulted in a $4 \%-6 \%$ (or $15 \%$ - $17 \%$ ) drop 
medRxiv preprint doi: https://doi.org/10.1101/2020.08.22.20179929; this version posted August 25, 2020. The copyright holder for this preprint (which was not certified by peer review) is the author/funder, who has granted medRxiv a license to display the preprint in perpetuity.

It is made available under a CC-BY-NC-ND 4.0 International license .

284 in the outbreak size, and a similar drop in the workday loss, compared to the baseline case. However,

285 the impact of reduction of contact rates was much greater under the higher efficacy of facemasks.

286 Implementing the quarantine policy (HCW screening and isolation) alone, even when all

287 symptomatic cases are included, would typically prolong the outbreak duration, but had a marginal

288 effect on its size, particularly under the existence of external (patient) source pressure. Our results

289 indicated that the low efficiency of symptomatic quarantine was due to a large share of transmission

290 being carried by pre-symptomatic/ asymptomatic $(E)$ individuals [36], and to the patient source.

291 Hence, a quarantine policy for HCWs should be augmented with other interventions to achieve a

292 significant reduction. Efficient control of the patient source (via the use of PPE, their screening and

293 isolation, and/or admission) is one key to mitigating the HCW outbreak. The effectiveness of all

294 these interventions was shown to increase with their early implementation.

295 To our knowledge, this study is the first of its kind to provide quantitative modelled assessment and

296 projections for COVID-19 transmission in hospital settings. However, the IBM methodology

297 developed here, has a far broader scope, beyond healthcare facilities. Indeed, with proper

298 adjustment, it could be applied to many other local communities (workplaces, schools, city

299 neighborhoods, et al). The key feature of such IBM is a fine-scale resolution of community makeup,

300 social interactions, and disease pathways. Such information is essential for risk assessment and the

301 development of efficient control/ intervention strategies on a local scale.

302 The current model setup is subject to some limitations. First, it was designed for a single hospital

303 unit and simplified treatment of the patient pool, as the target group in our study was HCW-pool.

304 More realistic local communities could combine multiple units (e.g. large hospital), with refined

305 population structure (e.g. patients, visitors, staff), and more complex interactions (e.g. 'random' and 
medRxiv preprint doi: https://doi.org/10.1101/2020.08.22.20179929; this version posted August 25, 2020. The copyright holder for this preprint (which was not certified by peer review) is the author/funder, who has granted medRxiv a license to display the preprint in perpetuity.

It is made available under a CC-BY-NC-ND 4.0 International license .

306 'scheduled' contact pools). Empirical data on these interactions will be required to adequately

307 parameterize such models. Second, although we have made an effort to characterize the SARS-CoV-

3082 transmission in a hospital setting, some parameters used in our setup were drawn from general

309 information sources, such as fractions of symptomatic mild and severe cases [37], disease stages and

310 durations [38], and associated infectivity levels [39], which may be adjusted in the future work.

\section{Conclusion}

312 Overall, our analysis shows that a COVID-19 outbreak among HCWs in a non-COVID-19 hospital

313 unit can be efficiently controlled /mitigated by non-pharmaceutical means. The most crucial factor of

314 success is high-efficacy facemasks for HCW contacts. It can be further augmented by social

315 distancing, screening/isolation, and patient source control.

\section{List of abbreviations}

317 World Health Organization (WHO); healthcare workers (HCWs); personal protective equipment 318 (PPE); Credible Interval (CrI). 
medRxiv preprint doi: https://doi.org/10.1101/2020.08.22.20179929; this version posted August 25, 2020. The copyright holder for this preprint (which was not certified by peer review) is the author/funder, who has granted medRxiv a license to display the preprint in perpetuity.

It is made available under a CC-BY-NC-ND 4.0 International license .

\section{Declarations}

Ethics approval and consent to participate

321 The study protocol was approved by the institutional ethics board of Union Hospital, Tongji Medical

322 College, Huazhong University of Science and Technology, Wuhan, China (No. 20200029). Written

323 informed consent was required before the data collecting, and participants were informed that they

324 could refuse to answer any question. The questionnaire did not ask about infection status, and no

325 biological samples were collected.

\section{Consent for publication}

327 Not applicable.

Availability of data and materials

329 The computer codes, including the aggregated data, implemented in the Wolfram Mathematica

330 platform are available in Githubs https://github.com/qimin-h/COVID-19-huang-et-al.-. All other

331 materials are available from the corresponding authors on reasonable request.

\section{Competing interests}

333 The authors declare that they have no competing interests.

\section{$334 \quad$ Funding}

335 This work was supported by the National Science Foundation RAPID Award [grant number DEB-

3362028631 to QH, AM, and DG], the National Science Foundation RAPID Award [grant number

337 DEB-2028632 to MN], and the Fundamental Research Funds for the Central Universities [grant

338 number 2020kfyXGYJ010 to XJ]; Funders had no role in study design, data collection, data analysis,

339 writing of the report, or the decision to submit for publication. The corresponding authors had full

340 access to all of the data and the final responsibility to submit for publication. 
medRxiv preprint doi: https://doi.org/10.1101/2020.08.22.20179929; this version posted August 25, 2020. The copyright holder for this preprint (which was not certified by peer review) is the author/funder, who has granted medRxiv a license to display the preprint in perpetuity.

It is made available under a CC-BY-NC-ND 4.0 International license .

$342 \mathrm{QH}, \mathrm{AM}$, and XJ contributed equally and shared the first authorship. QH, DG, AM, and MN

343 designed research, did model development, calibrations, and simulations, XJ, HZ, FF, PF, and WX

344 collected and provided hospital data, QH wrote the first draft, MN, DG, AM, and MAH made

345 critical revision of the manuscript. All the authors contributed to the interpretation of the study

346 results, read, comment, and approved the final version.

Acknowledgments

348 The authors would like to appreciate all healthcare workers in this study. XJ and HZ had full access

349 to all the data in the study and took responsibility for the integrity of the data.

\section{Reference}

351 1. Chinazzi M, Davis JT, Ajelli M, Gioannini C, Litvinova M, Merler S, y Piontti AP, Mu K, Rossi L, Sun K: The effect of travel restrictions on the spread of the 2019 novel coronavirus (COVID-19) outbreak. Science 2020, 368(6489):395-400.

354 2. Viner RM, Russell SJ, Croker H, Packer J, Ward J, Stansfield C, Mytton O, Bonell C, Booy R: School closure and management practices during coronavirus outbreaks including COVID-19: a rapid systematic review. The Lancet Child \& Adolescent Health 2020.

357 3. Pan A, Liu L, Wang C, Guo H, Hao X, Wang Q, Huang J, He N, Yu H, Lin X: Association of public health interventions with the epidemiology of the COVID-19 outbreak in

4. Flaxman S, Mishra S, Gandy A, Unwin HJT, Mellan TA, Coupland H, Whittaker C, Zhu H, 
medRxiv preprint doi: https://doi.org/10.1101/2020.08.22.20179929; this version posted August 25, 2020. The copyright holder for this preprint (which was not certified by peer review) is the author/funder, who has granted medRxiv a license to display the preprint in perpetuity.

It is made available under a CC-BY-NC-ND 4.0 International license .

363 5. Ferguson N, Laydon D, Nedjati Gilani G, Imai N, Ainslie K, Baguelin M, Bhatia S, Boonyasiri A, Cucunuba Perez Z, Cuomo-Dannenburg G: Report 9: Impact of nonpharmaceutical interventions (NPIs) to reduce COVID19 mortality and healthcare demand. 2020 .

367 6. Hellewell J, Abbott S, Gimma A, Bosse NI, Jarvis CI, Russell TW, Munday JD, Kucharski

7. Ferretti L, Wymant C, Kendall M, Zhao L, Nurtay A, Abeler-Dörner L, Parker M, Bonsall D, Fraser C: Quantifying SARS-CoV-2 transmission suggests epidemic control with digital contact tracing. Science 2020, 368(6491).

8. Ali ST, Wang L, Lau EH, Xu X-K, Du Z, Wu Y, Leung GM, Cowling BJ: Serial interval of 2020.

9. Chu DK, Akl EA, Duda S, Solo K, Yaacoub S, Schünemann HJ, El-harakeh A, Bognanni A, Lotfi T, Loeb M: Physical distancing, face masks, and eye protection to prevent personto-person transmission of SARS-CoV-2 and COVID-19: a systematic review and metaanalysis. The Lancet 2020.

10. Davies NG, Kucharski AJ, Eggo RM, Gimma A, Edmunds WJ, Jombart T, O'Reilly K, Endo A, Hellewell J, Nightingale ES: Effects of non-pharmaceutical interventions on COVID- 
medRxiv preprint doi: https://doi.org/10.1101/2020.08.22.20179929; this version posted August 25, 2020. The copyright holder for this preprint (which was not certified by peer review) is the author/funder, who has granted medRxiv a license to display the preprint in perpetuity.

It is made available under a CC-BY-NC-ND 4.0 International license .

384 11. Kucharski AJ, Russell TW, Diamond C, Liu Y, Edmunds J, Funk S, Eggo RM, Sun F, Jit M, Munday JD: Early dynamics of transmission and control of COVID-19: a mathematical modelling study. The lancet Infectious Diseases 2020.

387 12. Wu JT, Leung K, Leung GM: Nowcasting and forecasting the potential domestic and international spread of the 2019-nCoV outbreak originating in Wuhan, China: a modelling study. The Lancet 2020, 395(10225):689-697.

390 13. Koo JR, Cook AR, Park M, Sun Y, Sun H, Lim JT, Tam C, Dickens BL: Interventions to mitigate early spread of SARS-CoV-2 in Singapore: a modelling study. The Lancet

14. Miller JC, Qiu X, MacFadden D, Hanage WP: Evaluating the contributions of strategies to prevent SARS-CoV-2 transmission in the healthcare setting: a modelling study. medRxiv

15. Anderson RM, May RM: Infectious Diseases of Humans: Dynamics and Control: Oxford University Press; 1992.

16. Hethcote HW: The mathematics of infectious diseases. SIAM Review 2000, 42(4):599-653.

399 17. Giordano G, Blanchini F, Bruno R, Colaneri P, Di Filippo A, Di Matteo A, Colaneri M: interventions in Italy. Nature Medicine 2020:1-6.

402 18. Prem K, Liu Y, Russell TW, Kucharski AJ, Eggo RM, Davies N, Flasche S, Clifford S, Pearson CA, Munday JD: The effect of control strategies to reduce social mixing on 
medRxiv preprint doi: https://doi.org/10.1101/2020.08.22.20179929; this version posted August 25, 2020. The copyright holder for this preprint (which was not certified by peer review) is the author/funder, who has granted medRxiv a license to display the preprint in perpetuity.

It is made available under a CC-BY-NC-ND 4.0 International license .

19. Nguyen LH, Drew DA, Graham MS, Joshi AD, Guo C-G, Ma W, Mehta RS, Warner ET, Sikavi DR, Lo C-H: Risk of COVID-19 among front-line health-care workers and the general community: a prospective cohort study. The Lancet Public Health 2020.

409 20. McCauley L, Hayes R: Taking responsibility for front-line health-care workers. The Lancet Public Health 2020.

411 21. Chou R, Dana T, Buckley DI, Selph S, Fu R, Totten AM: Update alert: epidemiology of and risk factors for coronavirus infection in health care workers. Annals of Internal Medicine 2020.

414 22. Wong S-Y, Kwong R-S, Wu TC, Chan J, Chu M, Lee S, Wong H, Lung D: Risk of nosocomial transmission of coronavirus disease 2019: an experience in a general ward setting in Hong Kong. Journal of Hospital Infection 2020.

417 23. Ferguson NM, Cummings DA, Fraser C, Cajka JC, Cooley PC, Burke DS: Strategies for

24. Germann TC, Kadau K, Longini IM, Macken CA: Mitigation strategies for pandemic influenza in the United States. Proceedings of the National Academy of Sciences 2006, pandemic in the United States. Proceedings of the National Academy of Sciences 2008, 105(12):4639-4644.

426 26. D’Agata EM, Magal P, Olivier D, Ruan S, Webb GF: Modeling antibiotic resistance in hospitals: the impact of minimizing treatment duration. Journal of Theoretical Biology 2007, 249(3):487-499. 
medRxiv preprint doi: https://doi.org/10.1101/2020.08.22.20179929; this version posted August 25, 2020. The copyright holder for this preprint (which was not certified by peer review) is the author/funder, who has granted medRxiv a license to display the preprint in perpetuity.

It is made available under a CC-BY-NC-ND 4.0 International license .

429 27. Wei WE, Li Z, Chiew CJ, Yong SE, Toh MP, Lee VJ: Presymptomatic transmission of SARS-CoV-2-Singapore, January 23-March 16, 2020. Morbidity and Mortality Weekly Report 2020, 69(14):411.

432 28. Arons MM, Hatfield KM, Reddy SC, Kimball A, James A, Jacobs JR, Taylor J, Spicer K, Bardossy AC, Oakley LP: Presymptomatic SARS-CoV-2 infections and transmission in a

29. Kimball A, Hatfield KM, Arons M, James A, Taylor J, Spicer K, Bardossy AC, Oakley LP,

30. Bai Y, Wang X, Huang Q, Wang H, Gurarie D, Ndeffo-Mbah M, Fan F, Fu P, Horn MA, Xu study. medRxiv 2020.

442 31. Centers for Diseases Control and Prevention: Interim guidance on follow-up of close contacts of persons infected with novel Influenza A viruses associated with severe human disease and on the use of antiviral medications for Chemoprophylaxis. Updated

446 32. Tromberg BJ, Schwetz TA, Pérez-Stable EJ, Hodes RJ, Woychik RP, Bright RA, Fleurence 7(2):223-242. 
medRxiv preprint doi: https://doi.org/10.1101/2020.08.22.20179929; this version posted August 25, 2020. The copyright holder for this preprint (which was not certified by peer review) is the author/funder, who has granted medRxiv a license to display the preprint in perpetuity.

It is made available under a CC-BY-NC-ND 4.0 International license .

451 34. Gelman A, Rubin DB: Inference from iterative simulation using multiple sequences.

$452 \quad$ Statistical Science 1992, 7(4):457-472.

453 35. Anderson RM, Heesterbeek H, Klinkenberg D, Hollingsworth TD: How will country-based 454 mitigation measures influence the course of the COVID-19 epidemic? The Lancet 2020, $455 \quad 395(10228): 931-934$.

456 36. Rivett L, Sridhar S, Sparkes D, Routledge M, Jones NK, Forrest S, Young J, Pereira-Dias J, 457 Hamilton WL, Ferris M: Screening of healthcare workers for SARS-CoV-2 highlights the 458 role of asymptomatic carriage in COVID-19 transmission. Elife 2020, 9:e58728.

459 37. World Health Organization: Report of the WHO-China joint mission on coronavirus 460 disease 2019 (COVID-19). In.: Geneva; 2020.

461 38. Lauer SA, Grantz KH, Bi Q, Jones FK, Zheng Q, Meredith HR, Azman AS, Reich NG, 462 Lessler J: The incubation period of coronavirus disease 2019 (COVID-19) from publicly 463 reported confirmed cases: estimation and application. Annals of Internal Medicine 2020, $464 \quad$ 172(9):577-582.

465 39. Li R, Pei S, Chen B, Song Y, Zhang T, Yang W, Shaman J: Substantial undocumented 466 infection facilitates the rapid dissemination of novel coronavirus (SARS-CoV-2). Science $467 \quad 2020,368(6490): 489-493$. 


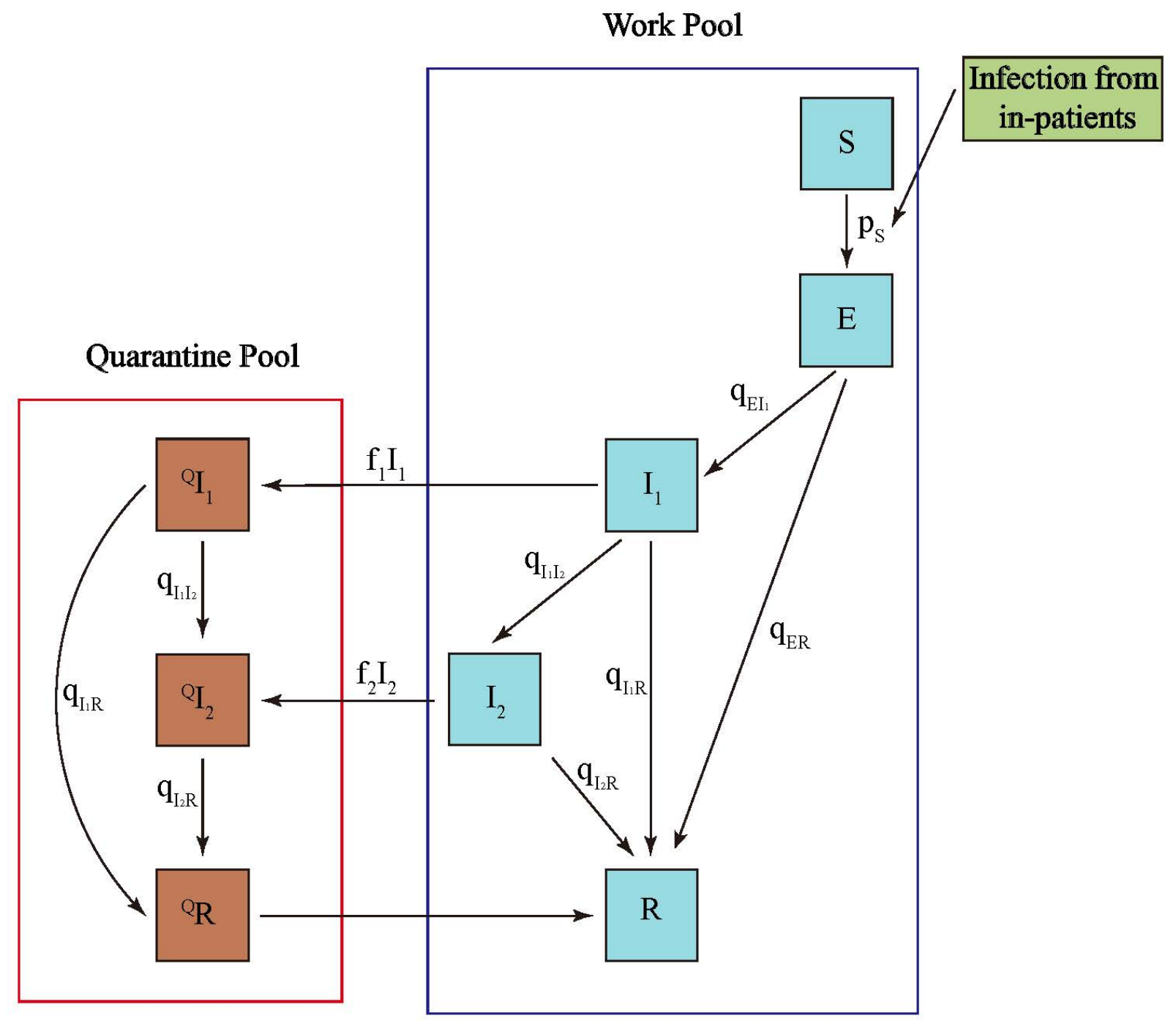

471 Figure 1: State transitions in the individual-based model. The standard SEIR scheme is used to

472 describe host states: $S$ - susceptible, $E$ - latent (pre-symptomatic/ asymptomatic but infectious), $I_{1}$ -

473 first symptomatic (upper respiratory infection), $I_{2}$ - second stage (advanced lung infection ), $R$ -

474 recovered/immune. Hosts can undergo three different pathways: asymptomatic $(E \rightarrow R)$; mild

475 symptomatic $\left(E \rightarrow I_{1} \rightarrow R\right)$; severe symptomatic $\left(E \rightarrow I_{1} \rightarrow I_{2} \rightarrow R\right)$. Depending on the screening

476 procedure, fractions of $\left(I_{2}, I_{2}\right)$ are sent to quarantine, and released to the workpool upon recovery. 
medRxiv preprint doi: https://doi.org/10.1101/2020.08.22.20179929; this version posted August 25, 2020. The copyright holder for this preprint (which was not certified by peer review) is the author/funder, who has granted medRxiv a license to display the preprint in perpetuity.

It is made available under a CC-BY-NC-ND 4.0 International license .

477 Infected patients are treated as an external source

(A)

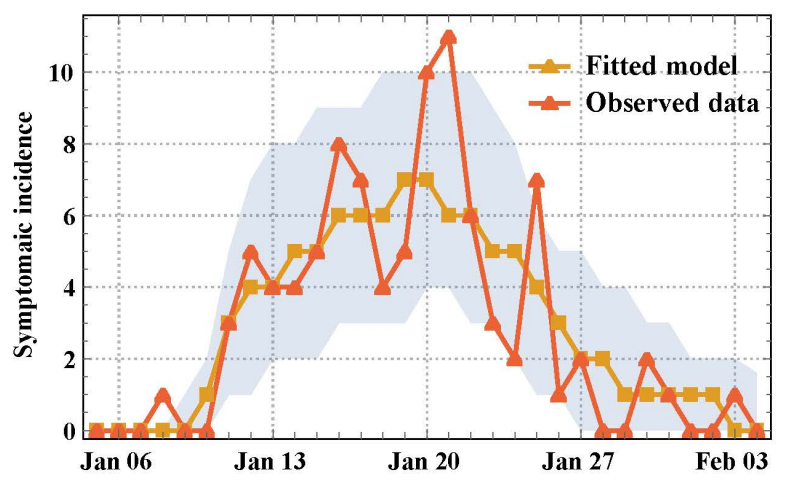

(C)

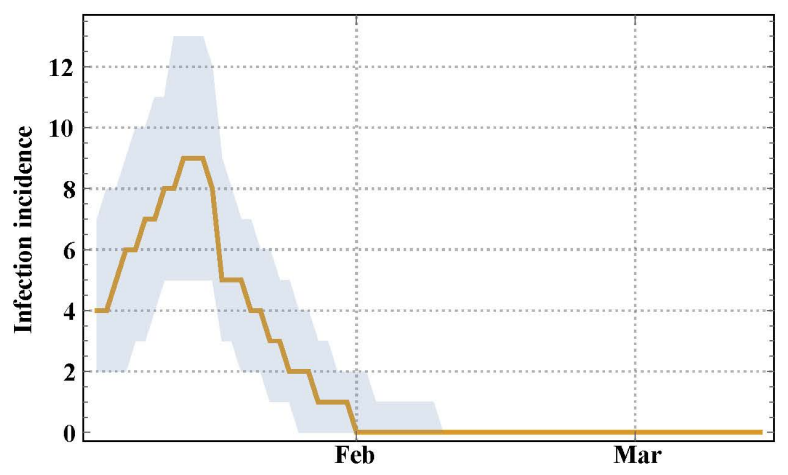

(B)

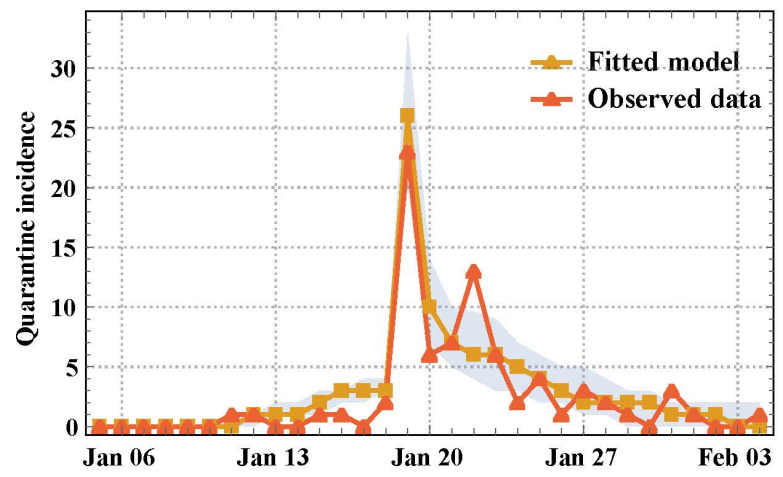

(D)

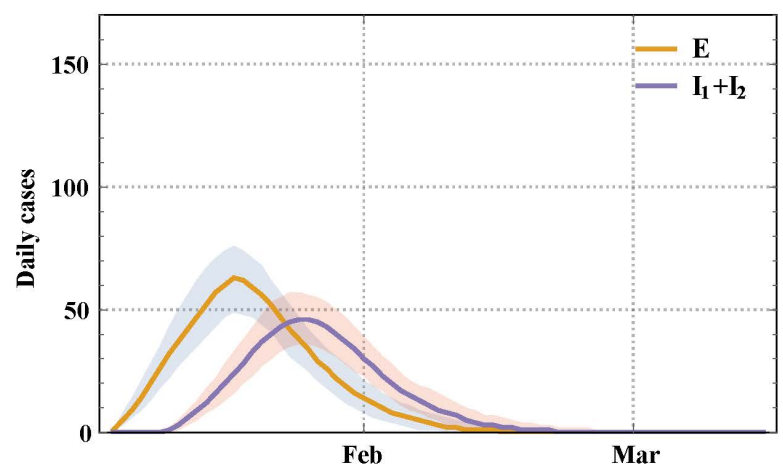

479 Figure 2: Model calibration and prediction. Panel A shows the observed and fitted daily incidence of symptomatic cases $\left(E \rightarrow I_{1}\right)$. Panel B shows the observed and fitted daily quarantine cases among

481 HCWs. Panel C shows the predicted infection incidence $(S \rightarrow E)$ from the calibrated model. Panel D

482 shows the corresponding predicted daily pre-symptomatic/ asymptomatic cases, $E$, and symptomatic

483 cases, $I_{1}+I_{2}$, respectively. The grey shaded regions are $90 \%$ credible intervals. 
(A)
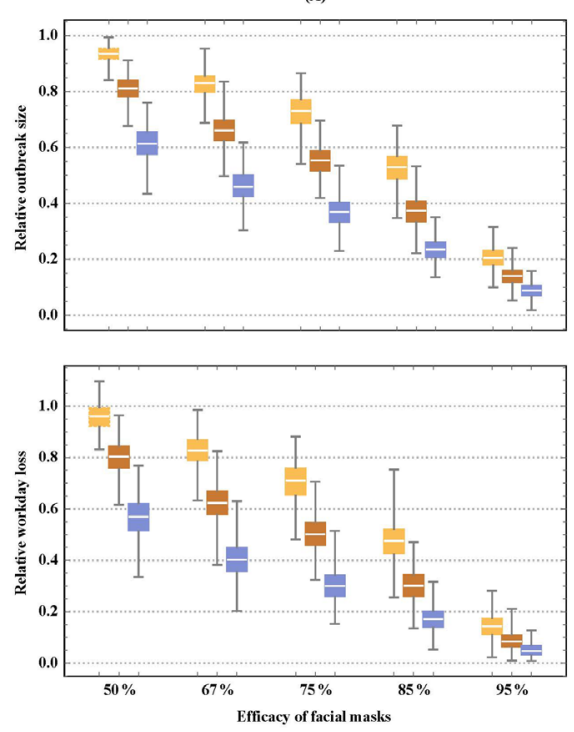

(B)
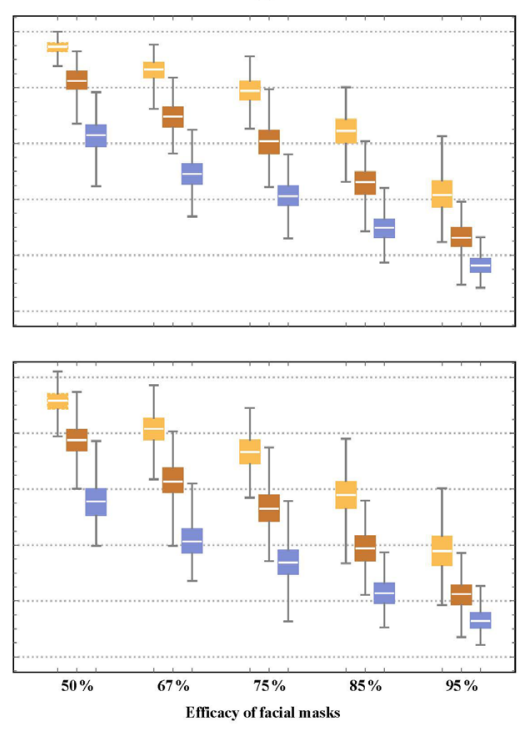

$\square$ baseline contact
(C)
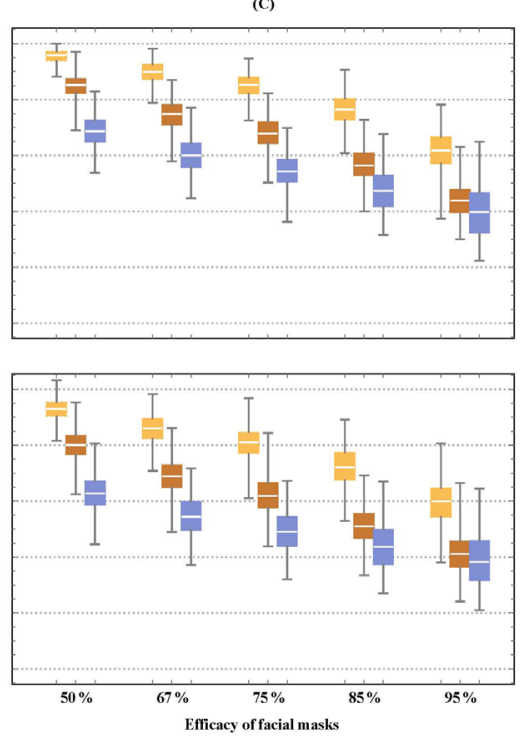

$\square 50 \%$ reduction of contacts $\square 75 \%$ reduction of contacts

485 Figure 3. The combined effect of facial masks and social distancing (reduced contact rate).

486 Three levels of social distancing were considered (normal, reduced by $50 \%$, reduced by $75 \%$ ). For

487 face-mask efficacy, we considered five putative values $(50 \%, 67 \%, 75 \%, 85 \%, 95 \%)$. The efficacy is

488 measured via reduced host susceptibility per contact $(a \rightarrow 0 \cdot 5 * a ; a \rightarrow 0 \cdot 33 * a \ldots)$. We also

489 considered different timing of preventive measures: (1) start of the outbreak (Panel A); (2) after the

490 first identified HCW case (Panel B); (3) after 10\% of HCW-staff got infected (Panel C). In each

491 case, we estimated the posterior distribution of the relative outbreak size, and the workday loss over

492 baseline values.

493 
medRxiv preprint doi: https://doi.org/10.1101/2020.08.22.20179929; this version posted August 25, 2020. The copyright holder for this preprint (which was not certified by peer review) is the author/funder, who has granted medRxiv a license to display the preprint in perpetuity.

It is made available under a CC-BY-NC-ND 4.0 International license .

(A)
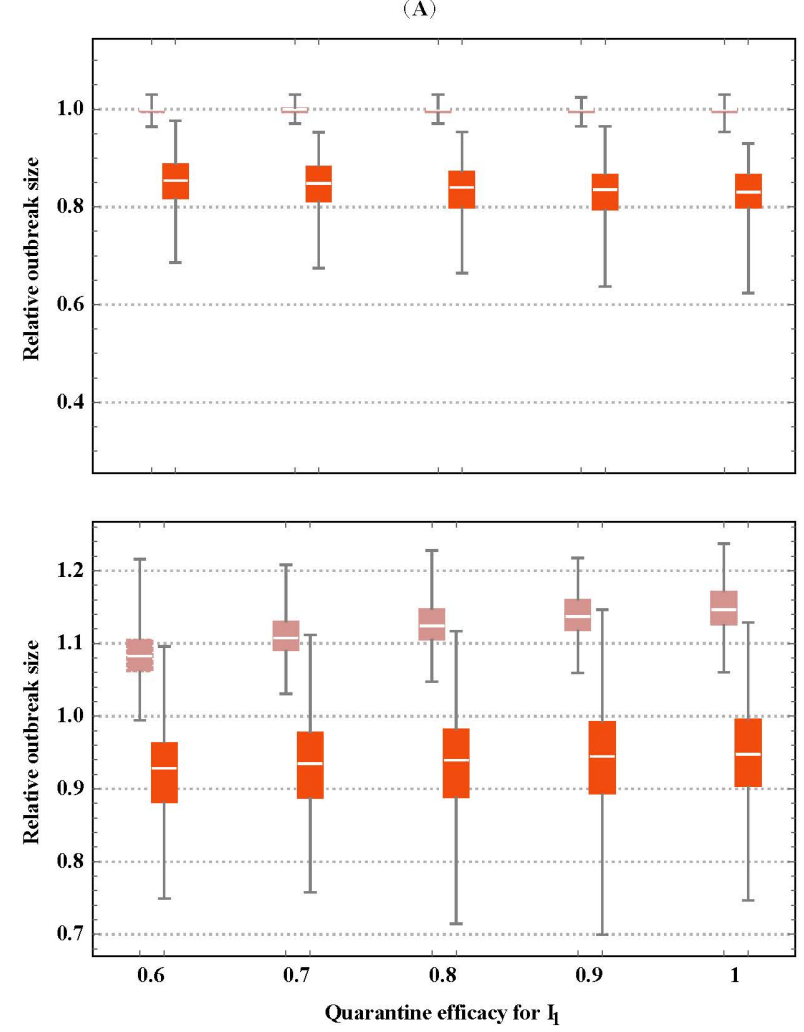
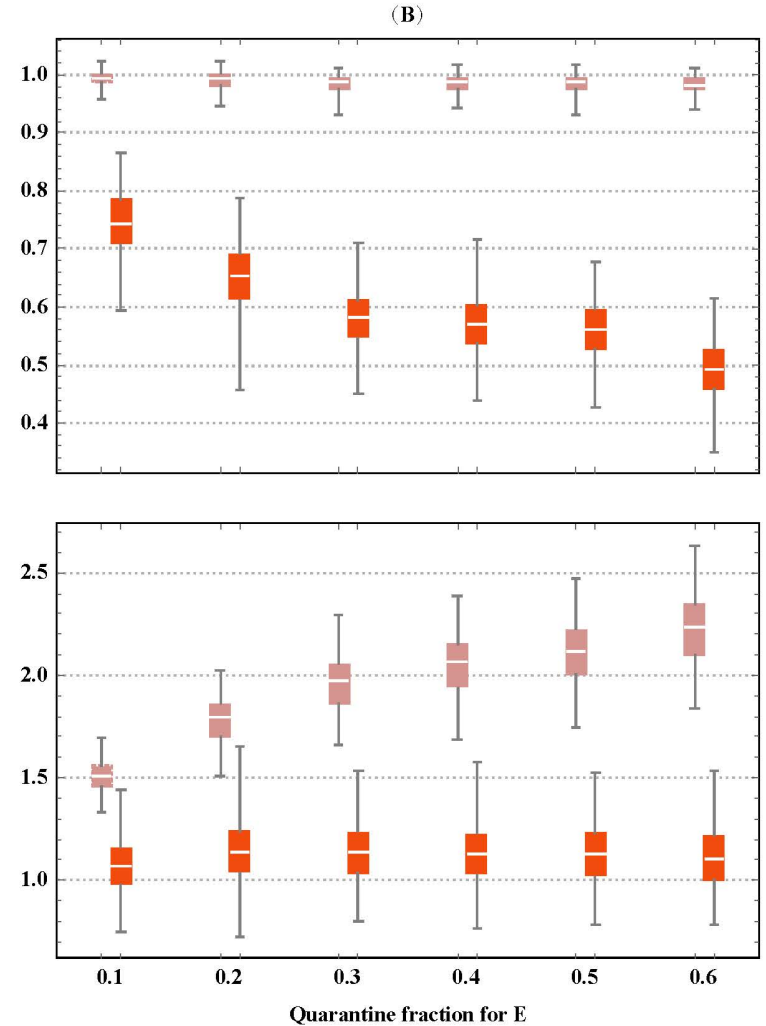

baseline patient infectivity
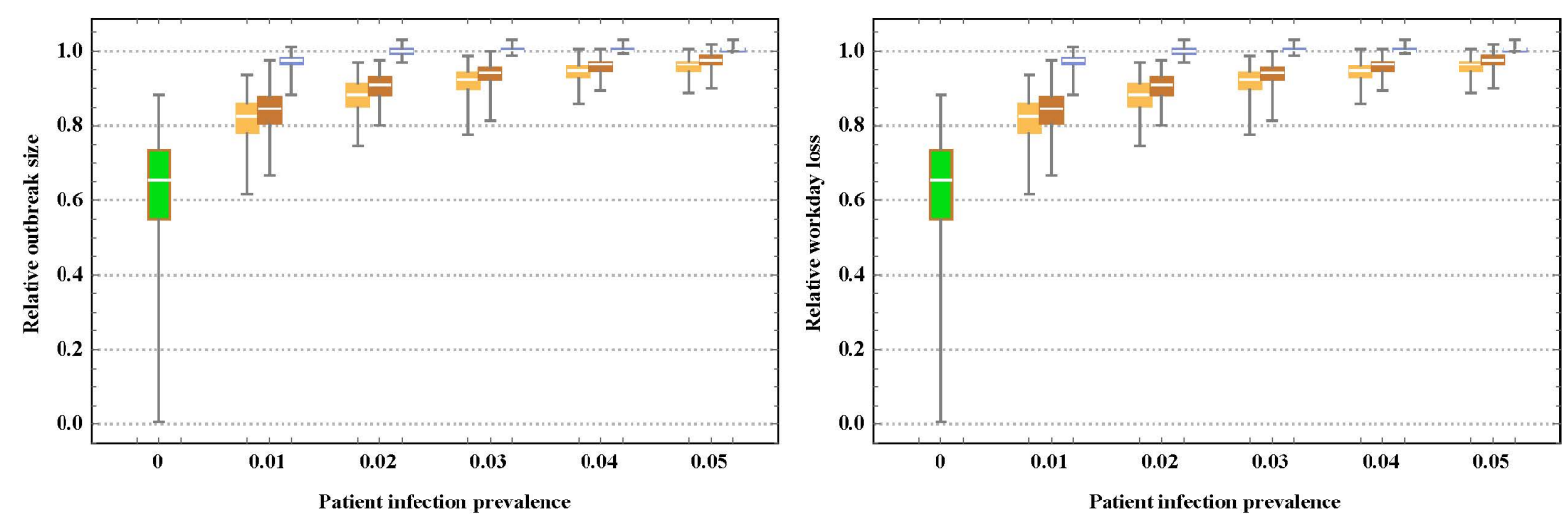

$\square$ no infection from in-patients

$\square$ decreased patient infectivity via PPEs at the beginning

$\square$ baseline patient infectivity

$\square$ decreased patient infectivity via PPEs after first identified case

Figure 4. The effect of the quarantine and patient sources on relative outbreak size and

workday loss. The patient sources (infection prevalence and infectivity) were controlled via 
medRxiv preprint doi: https://doi.org/10.1101/2020.08.22.20179929; this version posted August 25, 2020. The copyright holder for this preprint (which was not certified by peer review) is the author/funder, who has granted medRxiv a license to display the preprint in perpetuity. It is made available under a CC-BY-NC-ND 4.0 International license.

499 B). We used the following marking: (pink) baseline patient infection level, (red) reduced patient 500 infection by $80 \%$ via PPE use by HCWs. In column A, the quarantine fraction of moderate/severe 501 cases $\left(I_{2}\right)$ was fixed at $100 \%$, and the quarantine fraction of mild cases $\left(I_{1}\right)$ was varied from $60 \%$ to $502100 \%$. In column B, we fixed symptomatic $\left(I_{1} ; I_{2}\right)$ quarantine fractions at $(90 \%, 100 \%)$, and varied 503 the quarantine fraction of pre-symptomatic/ asymptomatic $E$-pool from $10 \%$ to $60 \%$.

504 Panel C shows the effect of patient infection and different timing of PPE use: i) start of the outbreak, 505 ii) after the first identified HCW infection, iii) no PPE use. We considered different levels of 506 prevalence of the infected patient pool: $0 \%, 1 \%, 2 \%$ (baseline value), $3 \%, 4 \%, 5 \%$. 


\section{Tables}

Table 1: Effects of implementing social distancing through reduction of contacts alone and wearing face masks alone, from the start of the outbreak. We simulated a six-month intervention-regimen for the calibrated model. The progress was measured in terms of outbreak size, workday loss, and cumulative quarantine incidence. Reasonable (50\% and 75\%) reduction of contact rates and levels of efficacy of facial masks $(50 \%, 67 \%, 75 \%, 85 \%, 95 \%)$ were chosen. The results shown are predicted median $(90 \%$ Credible Interval).

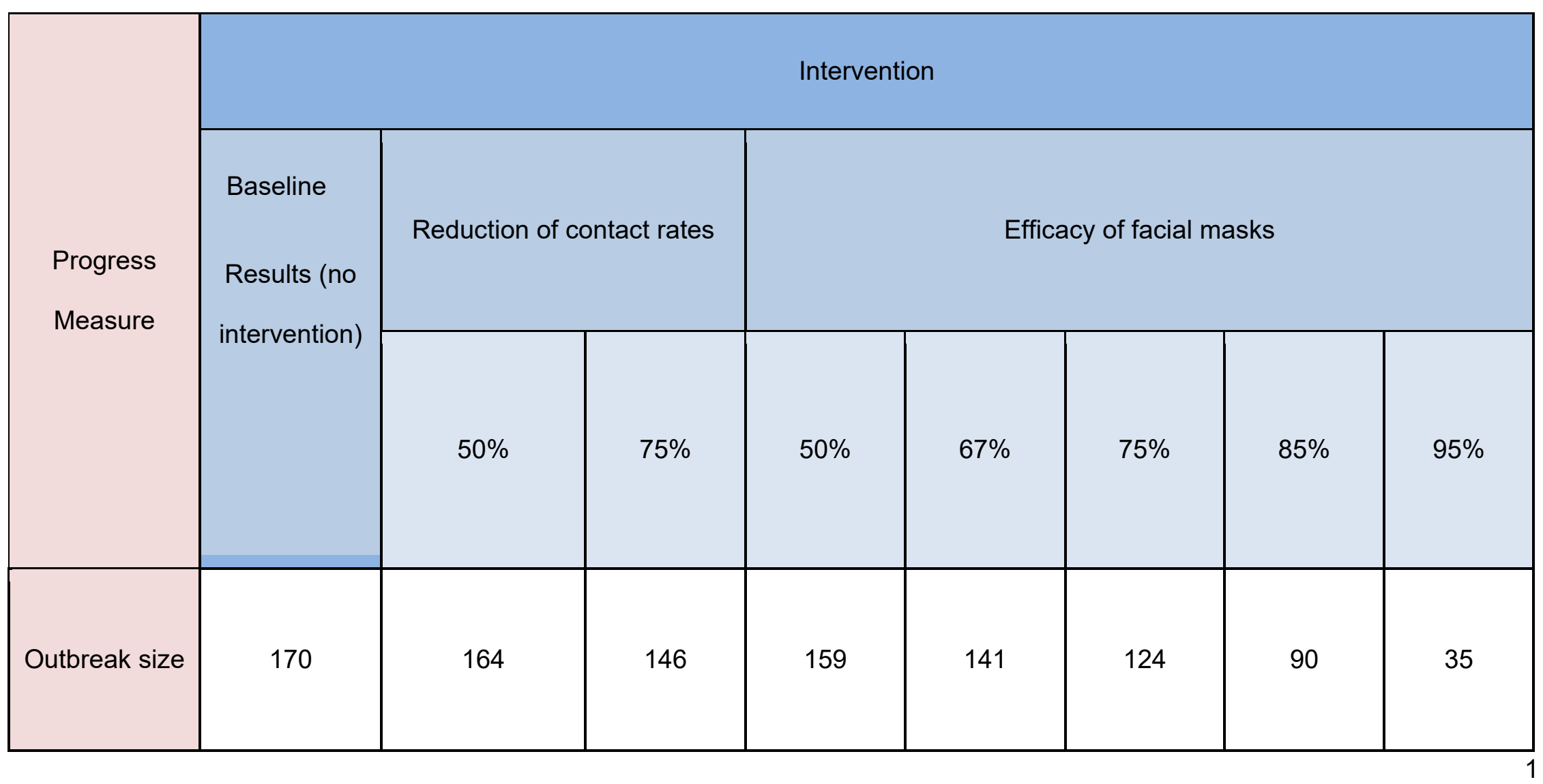




\begin{tabular}{|c|c|c|c|c|c|c|c|c|}
\hline & $(168-171)$ & $(159-169)$ & $(135-156)$ & $(150-165)$ & $(128-151)$ & $(108-137)$ & $(75-104)$ & $(24-46)$ \\
\hline Workday loss & $\begin{array}{c}1050 \\
(913-1282)\end{array}$ & $\begin{array}{c}992 \\
(855-1202)\end{array}$ & $\begin{array}{c}853 \\
(721-1044)\end{array}$ & $\begin{array}{c}950 \\
(817-1145)\end{array}$ & $\begin{array}{c}819 \\
(678-997)\end{array}$ & $\begin{array}{c}698 \\
(562-876)\end{array}$ & $\begin{array}{c}469 \\
(342-605)\end{array}$ & $\begin{array}{c}142 \\
(77-212)\end{array}$ \\
\hline $\begin{array}{l}\text { Cumulative } \\
\text { quarantine } \\
\text { incidence }\end{array}$ & $\begin{array}{c}112 \\
(98-136)\end{array}$ & $\begin{array}{c}107 \\
(93-130)\end{array}$ & $\begin{array}{c}93 \\
(80-113)\end{array}$ & $\begin{array}{c}103 \\
(89-123)\end{array}$ & $\begin{array}{c}90 \\
(76-108)\end{array}$ & $\begin{array}{c}78 \\
(63-96)\end{array}$ & $\begin{array}{c}53 \\
(40-68)\end{array}$ & $\begin{array}{c}16 \\
(9-24)\end{array}$ \\
\hline
\end{tabular}


medRxiv preprint doi: https://doi.org/10.1101/2020.08.22.20179929; this version posted August 25, 2020. The copyright holder for this preprint (which was not certified by peer review) is the author/funder, who has granted medRxiv a license to display the preprint in perpetuity.

It is made available under a CC-BY-NC-ND 4.0 International license .

\section{Supplementary information}

\section{Setup and parameters of the individual-base model}

The individual-based model we developed features a heterogeneous host population with distinct infective stages and transitions, different patterns of disease-progression (asymptomatic, mild, severe), individual risk factors (health status, work stress, et al), individual behavior including social mixing patterns among HCWs, use of PPE/ facial masks, and HCW-patient interactions.

The key inputs in IBM are described below:

1) Host community consists of three disease progress groups, asymptomatic, mild, severe (A-M-S), i.e., population fractions $\left(\boldsymbol{v}_{A}, \boldsymbol{v}_{\boldsymbol{M}}, v_{S}\right)$ that undergo three pathways of Figure 1: (A) asymptomatic $(E \rightarrow R)$; (M) mild symptomatic $\left(E \rightarrow I_{1} \rightarrow R\right)$; (S) severe symptomatic $\left(E \rightarrow I_{1} \rightarrow I_{2} \rightarrow R\right)$. Based on the WHO report [1], we assumed that for symptomatic cases, $80 \%$ are mild symptomatic, i.e., $v_{M}=0.8 *\left(1-v_{A}\right), v_{S}=0.2 *\left(1-v_{A}\right)$, Fraction $v_{A}$ was estimated at 0.3080 (90\% Credible Interval (CrI): 0.1628 - 0.3948) using the Bayesian method, consequently, we get $\left(v_{M}, v_{S}\right)$ equal to $(0.5536 ; 0.1384)$;

2) Initial infection state. We assume that only one $\mathrm{HCW}$ was in the latent $\mathrm{E}$ stage at the beginning of the simulation, while the rest 170 HCWs were susceptible;

3) Stage-specific infectivity levels $\left(b_{0}, b_{1}, b_{2}\right)$ for $\left(E, I_{1}, I_{2}\right)$. We assume $b_{1}=b_{2}$, for symptomatic groups $\left(I_{1}, I_{2}\right)$, while asymptomatic infectivity $b_{0}=0.55 * b_{1}$ [2]. Then we calibrated $b_{1}$ to be 0.2245 ( $90 \%$ CrI: $0.202-0.262$ ) using the Bayesian method, consequently, $b_{0}=0.124$ (90\% CrI: $\left.0.111-0.144\right)$;

4) Individual susceptibility level (a). In general, $a$ may depend on host health /immune status, individual behavior e.g. use of facial masks or PPE, and environmental conditions, $a=0$ (fully protected), $a=1$ (fully susceptible). Work stress is another factor that can affect susceptibility. According to [3] around $40 \% \mathrm{HCWs}$ claimed stress during the outbreak. Hence, we allowed $60 \% \mathrm{HCW}$ s to have a baseline susceptibility, $a_{N}=0.5$, while high-risk (stressed) pool, $40 \%$ of HCWs, with susceptibility level $0.5<a_{S}<1$ (to be calibrated by the Bayesian method). 5) The average duration of infective stages for each pathway. According to the published studies [1, 4-8], we fixed the average duration $L_{E R}$ of asymptomatic path $(E \rightarrow R)$ to be 10 days; the average durations $\left(L_{E I_{1}}, L_{I_{1} R}\right)$ of mild symptomatic path $\left(E \rightarrow I_{1} \rightarrow R\right)$ to be $(5 ; 9)$ days; and the average durations $\left(L_{E I_{1}}, L_{I_{1} I_{2}}, L_{I_{2} R}\right)$ of severe symptomatic path $\left(E \rightarrow I_{1} \rightarrow I_{2} \rightarrow R\right)$ to be $(5 ; 3 ; 14)$ days. 
medRxiv preprint doi: https://doi.org/10.1101/2020.08.22.20179929; this version posted August 25, 2020. The copyright holder for this preprint (which was not certified by peer review) is the author/funder, who has granted medRxiv a license to display the preprint in perpetuity.

It is made available under a CC-BY-NC-ND 4.0 International license .

6) Social mixing patterns between HCW, and external patient sources; Intra-HCW contacts were simulated as daily aggregation in small groups of 2,3, or 4 hosts, randomly drawn from the current working HCW pool. The basic case (full HCW working pool) assumes 60 pair-contacts, 30 triple-contacts, 8 quadruple-contacts per day. It

approximately gives a 2.2 contact rate per HCW-host per day from hospital data (Figure S2) [3]. Larger host aggregations are possible, but we ignore them here. Besides internal mixing, each HCW-host visited patients at a prescribed rate $=20 /$ per day. Unlike HCW staff, the patients were not individualized, but a random patient cluster (determined by mean visitation number per day) was drawn from the total patient pool (200) with a prescribed infected fraction (0.02), using a hypergeometric distribution. According to hospital data, no new patients were admitted after January 19th, and their pool was discharged after January 19th, at a rate of 5\% /day, and HCWs will wear PPEs in face of patients after Jan 19 th, so we assume patient infectivity, $b_{P P E}$, is decreased to be 0.02 , i.e., the efficacy of PPE is about decreasing risk of infection by $80 \%$, when we calibrated our IBM.

7) Daily isolation of symptomatic cases and recovery. We assumed that HCWs expressing symptoms are tested, and prescribed fractions $\left(f_{1} ; f_{2}\right)$ of $\left(I_{1} ; I_{2}\right)$ put in isolation. The assumed quarantine fractions $\left(0<f_{i}<1\right)$ combine limited test sensitivity, and overlapping 'COVID-like' symptoms, expressed by other (non-COVID) hosts. According to data, the Union Hospital in Wuhan has much more strict quarantine policy after January 19th, when they were aware of the seriousness of COVID-19, so we fixed $f_{1}$ to be $0 \cdot 1$ and $0 \cdot 8$ before and after January 19th, respectively, and fixed $f_{2}$ to be 0.15 and 0.85 before and after Jan 19th, respectively, when we calibrated our IBM. 


\section{Supplementary tables and figures}

Table S1. IBM inputs and parameters.

\begin{tabular}{|c|c|c|c|}
\hline Parameter & Descriptions & Value & Source \\
\hline$\left(a_{N} ; a_{S}\right)$ & $\begin{array}{l}\text { Susceptibility of a susceptible individual without } \\
\text { stress and with stress }\end{array}$ & $(0.5 ; 0.7608)$ & Calibrated \\
\hline & Percentage of HCWs without and with stress & $(0.6,0.4)$ & Data [3] \\
\hline$\left(b_{0}, b_{1}\right)$ & $\begin{array}{l}\text { Infectivity of an asymptomatic and symptomatic } \\
\text { infectious individual, respectively }\end{array}$ & $(0.1235,0.2245)$ & Calibrated [2] \\
\hline$\left(b_{0}, b_{P P E}\right)$ & $\begin{array}{l}\text { Infectivity of patient before January 19th and after } \\
\text { January 19th (because of PPE), respectively }\end{array}$ & $(0.1235,0.02)$ & $\begin{array}{l}\text { Estimated based } \\
\text { on hospital policy }\end{array}$ \\
\hline$\left(n_{2}, n_{3}, n_{4}\right)$ & $\begin{array}{l}\text { Number of random pair, triple, quadruple contacts } \\
\text { per day among HCWs }\end{array}$ & $(60 ; 30 ; 8)$ & $\begin{array}{l}\text { Typical } \\
\text { contacts/day }\end{array}$ \\
\hline$L_{E R}$ & The average duration of asymptomatic $(E \rightarrow R)$ & 10 & {$[1,4-8]$} \\
\hline$\left(L_{E I_{1}}, L_{I_{1} R}\right)$ & $\begin{array}{l}\text { The average duration of mild symptomatic }(E \rightarrow \\
\left.I_{1} \rightarrow R\right)\end{array}$ & $(5 ; 9)$ & {$[1,4-8]$} \\
\hline$\left(L_{E I_{1}}, L_{I_{1} I_{2}}, L_{I_{2} R}\right)$ & $\begin{array}{l}\text { The average duration of moderate/severe } \\
\text { symptomatic }\left(E \rightarrow I_{1} \rightarrow I_{2} \rightarrow R\right)\end{array}$ & $(5 ; 3 ; 14)$ & {$[1,4-8]$} \\
\hline$q$ & $\begin{array}{l}\text { Transition rate of disease progression based on } \\
\text { average duration and days }\end{array}$ & $\frac{(d / L)^{m}}{1+(d / L)^{m}}$ & \\
\hline
\end{tabular}


medRxiv preprint doi: https://doi.org/10.1101/2020.08.22.20179929; this version posted August 25, 2020. The copyright holder for this preprint (which was not certified by peer review) is the author/funder, who has granted medRxiv a license to display the preprint in perpetuity.

It is made available under a CC-BY-NC-ND 4.0 International license.

\begin{tabular}{|c|c|c|c|}
\hline$f_{1}$ & $\begin{array}{l}\text { Screening/ diagnostic fraction of mild } \\
\text { symptomatic infectious population before and } \\
\text { after January } 19^{\text {th }}, 2020 \text {, respectively; }\end{array}$ & $(0.1 ; 0.8)$ & $\begin{array}{l}\text { Estimated based } \\
\text { on hospital policy. }\end{array}$ \\
\hline$f_{2}$ & $\begin{array}{l}\text { Screening/ diagnostic fraction of severe } \\
\text { symptomatic infectious population before and } \\
\text { after January } 19^{\text {th }}, 2020 \text {. }\end{array}$ & $(0.15 ; 0.85)$ & $\begin{array}{l}\text { Estimated based } \\
\text { on hospital policy. }\end{array}$ \\
\hline$\left(v_{A}, v_{M}, v_{S}\right)$ & $\begin{array}{l}\text { Fraction of populations goes through three paths } \\
\text { of disease progression (1) asymptomatic }(E \rightarrow \\
R) \text {; (2) mild symptomatic }\left(E \rightarrow I_{1} \rightarrow R\right) \text {; (3) } \\
\text { moderate/severe symptomatic }\left(E \rightarrow I_{1} \rightarrow I_{2} \rightarrow\right. \\
R)\end{array}$ & $\begin{array}{l}(0.3080 ; 0.5536 ; \\
0.1384)\end{array}$ & Calibrated [1] \\
\hline \multicolumn{4}{|c|}{ External source from patients } \\
\hline & $\begin{array}{l}\text { average number of visits to patients per HCW per } \\
\text { day; the number of infectious patients, the total } \\
\text { number of patients }\end{array}$ & $(20 ; 4 ; 200)$ & Data \\
\hline Initial symbols & Description & Values & Source \\
\hline$\left(S_{0}, E_{0}\right)$ & $\begin{array}{l}\text { initial susceptible population; initial exposed } \\
\text { population }\end{array}$ & $(170 ; 1)$ & Data \\
\hline
\end{tabular}




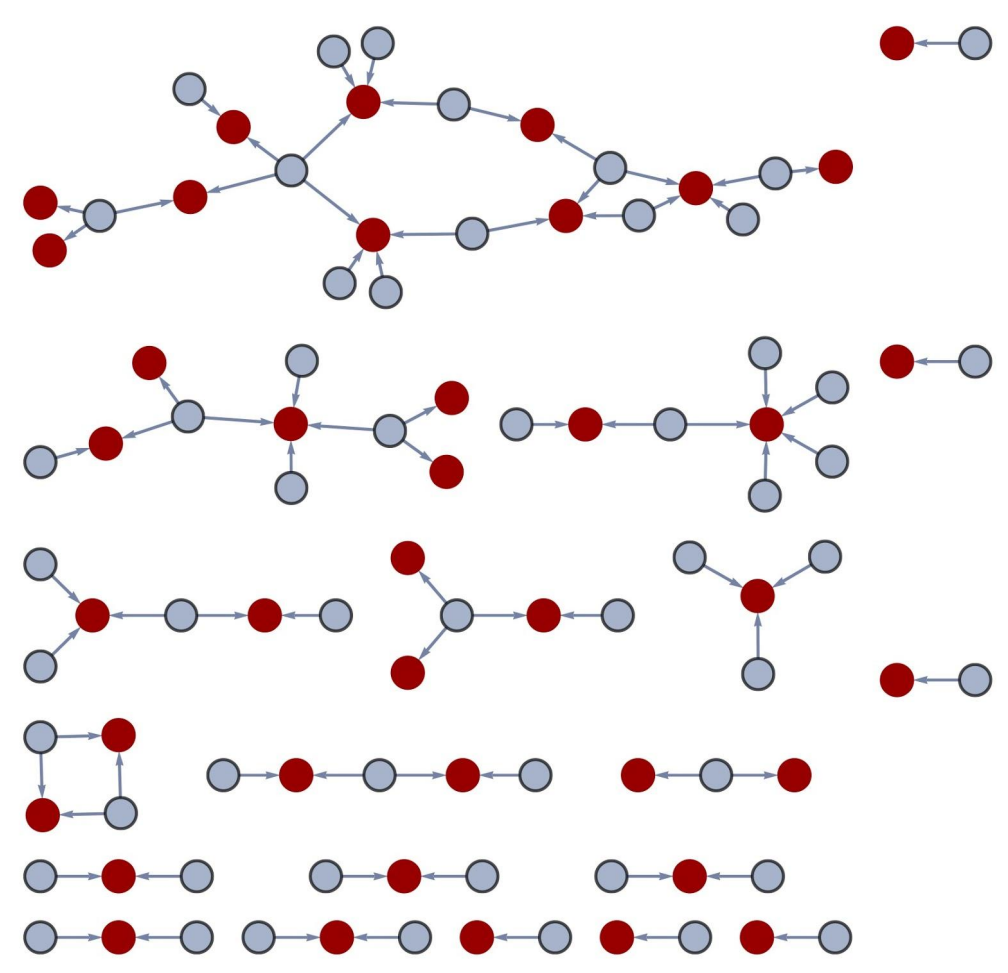

$1 \rightarrow 7,24,39,141$
$5 \rightarrow 7,47,139$
$7 \rightarrow 1,5,39,47,99,139$
$17 \rightarrow 79,166$
$24 \rightarrow 1,166$
$39 \rightarrow 1,7,28,168$
$47 \rightarrow 5,7,41,71,93,134,139$
$79 \rightarrow 10,17,18,77,97,146,166$
$141 \rightarrow 1,98,104,155$
$166 \rightarrow 17,24,79$

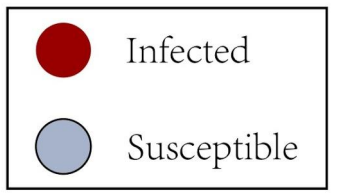

Figure S1. A typical daily snapshot of transmission pathways resulting from random mixing. Table at the bottom shows selected contact pools, and the graph arrows indicate which susceptible hosts (grey) were potentially in contact with infective $(E-I)$ hosts (red). In our scheme, a single 'red' can infect multiple susceptibles, and a susceptible (grey) can be linked to multiple infectives. 


\section{Distribution of daily contact rate}

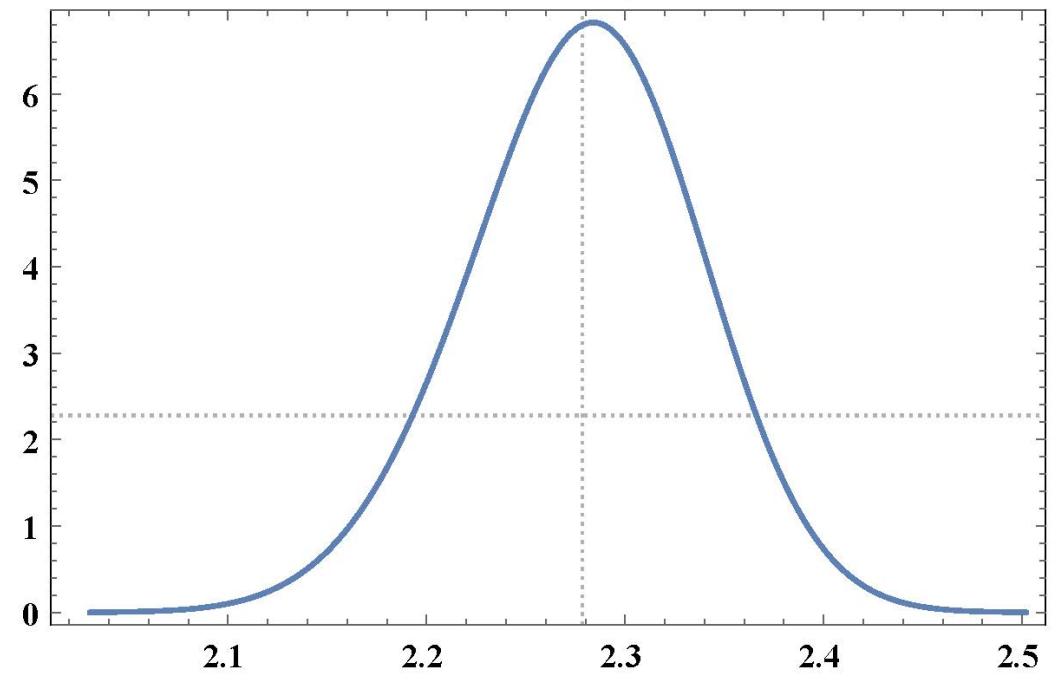

Figure S2. Distribution of baseline contact. The basic case (full HCW working pool) assumes 60 pair-contacts, 30 triple-contacts, 8 quadruple-contacts per day. It approximately gives a 2.2 contact rate per HCW-host per day. 
(A)

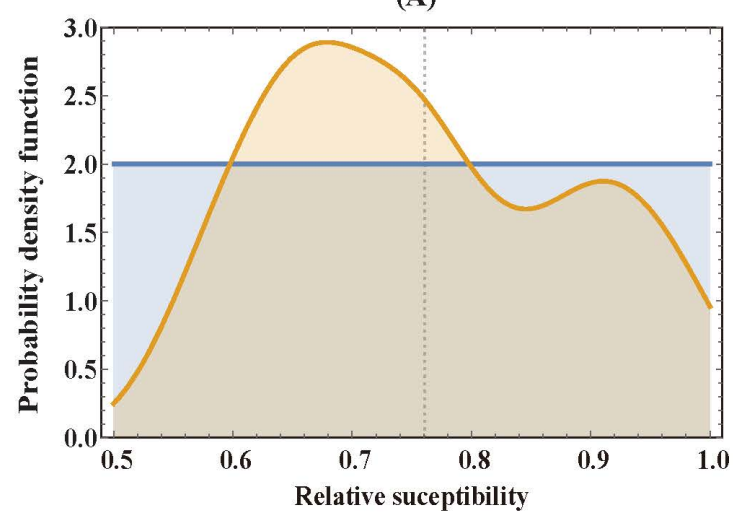

(C)

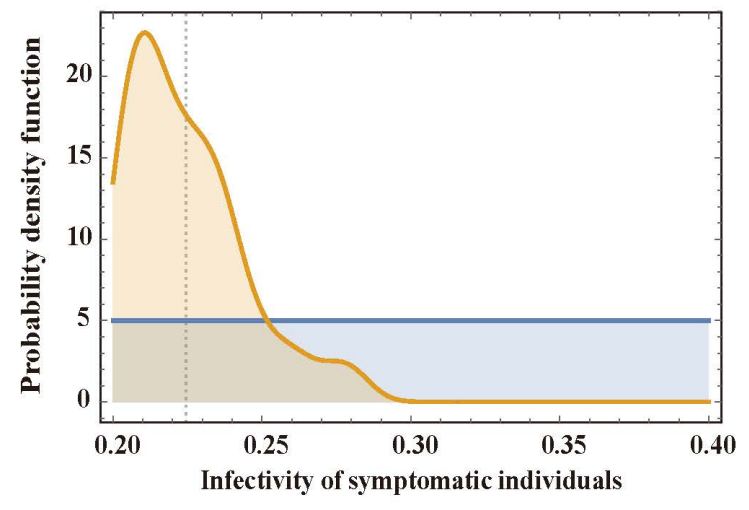

(B)

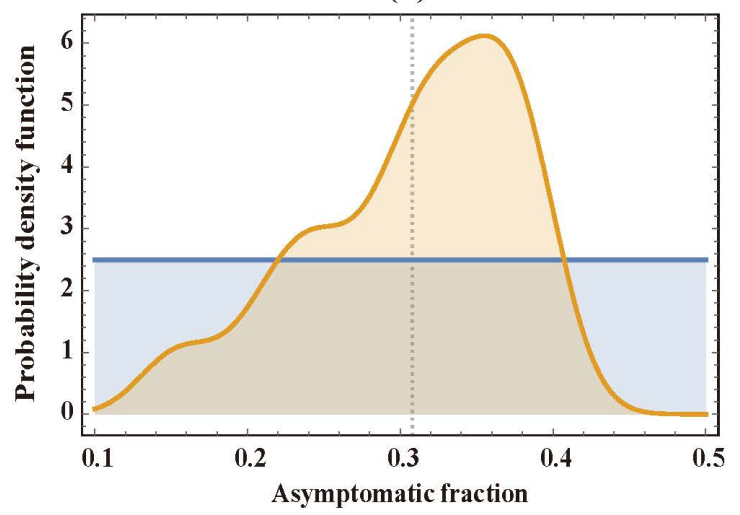

Asymptomatic fraction

Figure S3. The prior and posterior distribution for key parameters. Panel (A): relative susceptibility, $a_{S}$, of the stressed HCWs when compared to a baseline susceptibility of $a_{N}=0.5$; The prior distribution of $a$ was uniform in $(0.5,1)$ and the posterior was estimated to be $0.7608(90 \% \mathrm{CrI}: 0.5822-0.9653)$. Panel (B): asymptomatic fraction, $v_{A}$, i.e., the fraction of the HCWs which goes through the asymptomatic pathway $(E \rightarrow R)$. The prior distribution of $v_{A}$ was uniform in $(0.1,0.5)$ and the posterior was estimated to be $0 \cdot 3080(90 \%$ CrI: $0.1628-0.3948)$. Panel (C): infectivity of a symptomatic individual, $b_{1}$. The prior distribution of $b_{1}$ was uniform in $(0.2,0.4)$ and the posterior was estimated to be 0.2245 (90\% CrI: $0.202-0.262)$. 
(A)

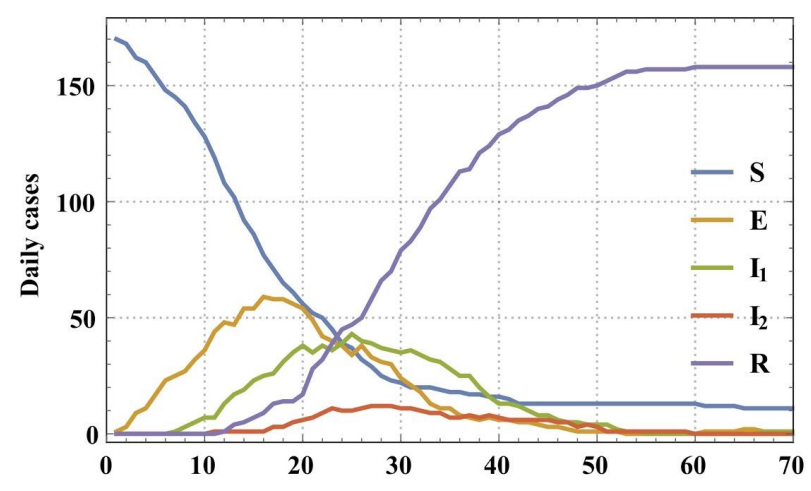

(C)

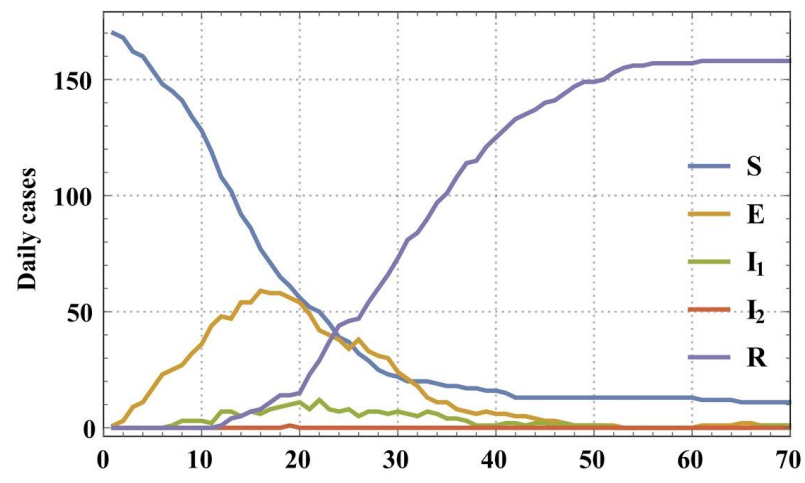

(E)

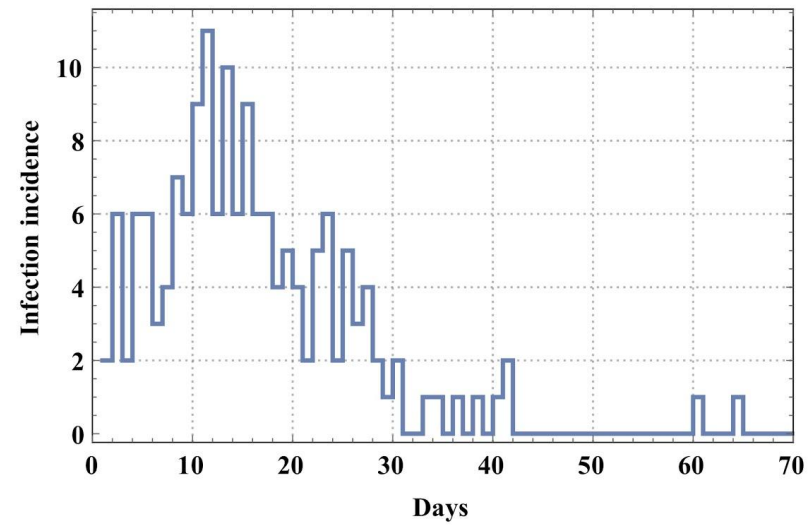

(B)

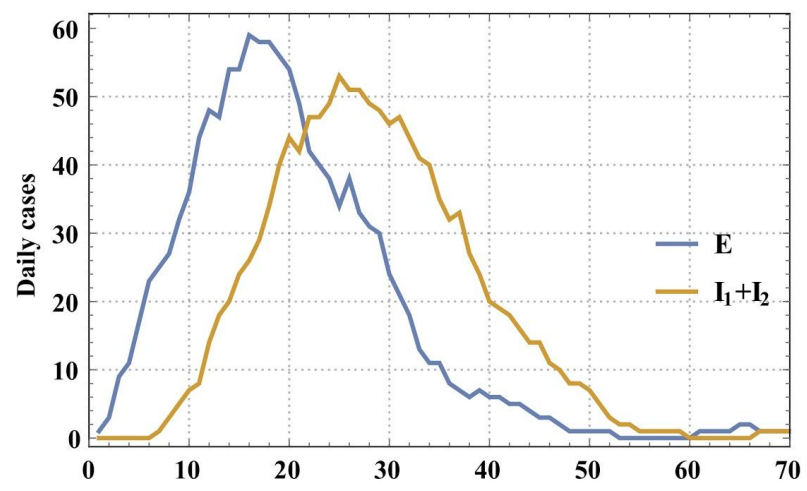

(D)

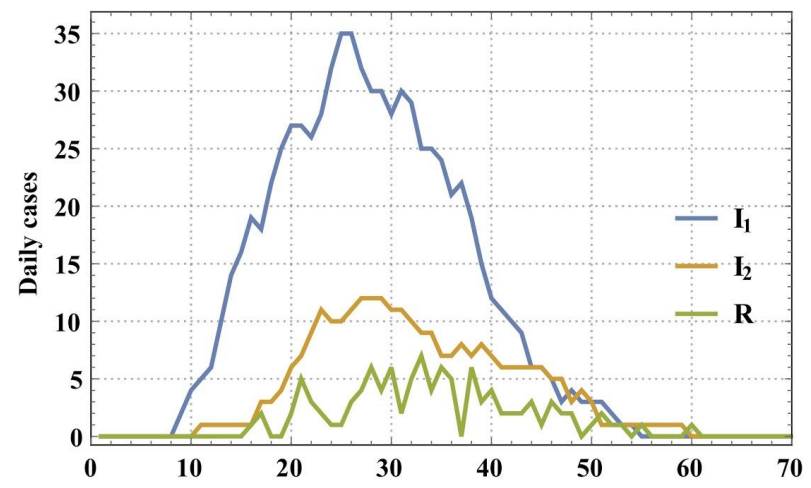

(F)

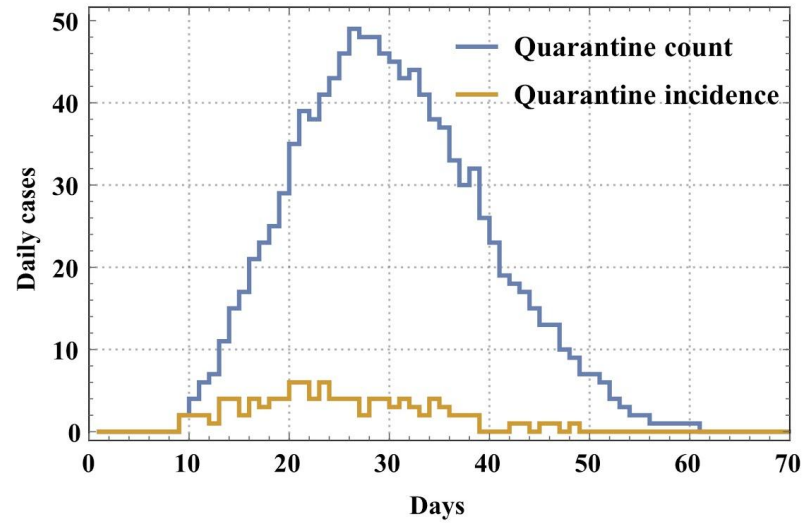

Figure S4. Typical outbreak history over a 70-day period for a baseline case. Panel (A) shows the outbreak history of the combined pool (work pool+quarantine pool); Panel (B) shows the simulation of asymptomatic, $E$, and symptomatic cases, $I_{1}+I_{2}$, in the combined pool. Panels (C) and (D) show the history of the work pool and 
medRxiv preprint doi: https://doi.org/10.1101/2020.08.22.20179929; this version posted August 25, 2020. The copyright holder for this preprint (which was not certified by peer review) is the author/funder, who has granted medRxiv a license to display the preprint in perpetuity.

It is made available under a CC-BY-NC-ND 4.0 International license .

quarantine pool, respectively. Panel (E) shows daily infection incidence $(S \rightarrow E)$. Panel (F) shows daily quarantine incidence (yellow) and quarantine count (blue), respectively.

\section{Reference}

1. World Health Organization, Organization WH: Report of the WHO-China joint mission on coronavirus disease 2019 (COVID-19). In.: Geneva; 2020.

2. $\quad$ Li R, Pei S, Chen B, Song Y, Zhang T, Yang W, Shaman J: Substantial undocumented infection facilitates the rapid dissemination of novel coronavirus (SARS-CoV-2). Science 2020, 368(6490):489493.

3. $\quad$ Bai Y, Wang X, Huang Q, Wang H, Gurarie D, Ndeffo-Mbah M, Fan F, Fu P, Horn MA, Xu S: SARSCoV-2 infection in health care workers: a retrospective analysis and a model study. medRxiv 2020.

4. Lauer SA, Grantz KH, Bi Q, Jones FK, Zheng Q, Meredith HR, Azman AS, Reich NG, Lessler J: The incubation period of coronavirus disease 2019 (COVID-19) from publicly reported confirmed cases: estimation and application. Annals of Internal Medicine 2020, 172(9):577-582.

5. Guan W-j, Ni Z-y, Hu Y, Liang W-h, Ou C-q, He J-x, Liu L, Shan H, Lei C-l, Hui DS: Clinical characteristics of coronavirus disease 2019 in China. New England Journal of Medicine 2020, 382(18):1708-1720.

6. $\quad \mathrm{Wu} Z, \mathrm{McGoogan} \mathrm{JM}$ : Characteristics of and important lessons from the coronavirus disease 2019 (COVID-19) outbreak in China: summary of a report of 72314 cases from the Chinese Center for Disease Control and Prevention. Jama 2020, 323(13):1239-1242.

7. Li Q, Guan X, Wu P, Wang X, Zhou L, Tong Y, Ren R, Leung KS, Lau EH, Wong JY: Early transmission dynamics in Wuhan, China, of novel coronavirus-infected pneumonia. New England Journal of Medicine 2020.

8. Huang C, Wang Y, Li X, Ren L, Zhao J, Hu Y, Zhang L, Fan G, Xu J, Gu X: Clinical features of patients infected with 2019 novel coronavirus in Wuhan, China. The lancet 2020, 395(10223):497-506. 